\title{
Post-Mortem Interval Estimation Based on Insect Evidence: Current Challenges
}

\author{
Szymon Matuszewski ${ }^{1,2}$ (D)
}

1 Laboratory of Criminalistics, Adam Mickiewicz University, Święty Marcin 90, 61-809 Poznań, Poland; szymmat@amu.edu.pl

2 Wielkopolska Centre for Advanced Technologies, Adam Mickiewicz University, Uniwersytetu Poznańskiego 10, 61-614 Poznań, Poland

Simple Summary: The post-mortem interval of human cadavers may be estimated based on insect evidence. In order to identify scientific challenges that pertain to these estimations, I review forensic entomology literature and conclude that research on the development and succession of carrion insects, thermogenesis on cadavers and the accuracy of PMI estimates are of primary importance to advance this field.

check for updates

Citation: Matuszewski, S.

Post-Mortem Interval Estimation Based on Insect Evidence: Current Challenges. Insects 2021, 12, 314. https://doi.org/10.3390/ insects12040314

Academic Editor: Daniel Martín-Vega

Received: 28 February 2021

Accepted: 29 March 2021

Published: 1 April 2021

Publisher's Note: MDPI stays neutra with regard to jurisdictional claims in published maps and institutional affiliations.

Copyright: (c) 2021 by the author Licensee MDPI, Basel, Switzerland. This article is an open access article distributed under the terms and conditions of the Creative Commons Attribution (CC BY) license (https:// creativecommons.org/licenses/by/ $4.0 /)$.
Abstract: During death investigations insects are used mostly to estimate the post-mortem interval (PMI). These estimates are only as good as they are close to the true PMI. Therefore, the major challenge for forensic entomology is to reduce the estimation inaccuracy. Here, I review literature in this field to identify research areas that may contribute to the increase in the accuracy of PMI estimation. I conclude that research on the development and succession of carrion insects, thermogenesis in aggregations of their larvae and error rates of the PMI estimation protocols should be prioritized. Challenges of educational and promotional nature are discussed as well, particularly in relation to the collection of insect evidence.

Keywords: forensic entomology; carrion insects; development; succession; validation

\section{Introduction}

Carrion insects living in human cadavers can be highly useful for the estimation of the post-mortem interval (PMI) [1,2]. Methods for PMI estimation based on insect evidence are developed, validated, improved and applied by forensic entomologists. This field is growing with a constant increase in the number of scientific publications and countries where entomology-based estimation of PMI is regularly used in death investigations [3,4]. As a maturing field, forensic entomology contains several weaknesses and under-researched areas. These challenges are the focus of this article.

A PMI estimate is only as good as it is close to the true PMI. The accuracy of estimation is most important, particularly for the end users of insect evidence. Therefore, the major general challenge for the field is to reduce the estimation inaccuracy. Its sources are related to both the collection and analysis of insect evidence (Figure 1). I divided this paper into sections devoted to the collection of insect evidence, research on insect development and succession, reconstructing temperature conditions, analysis of challenging evidence and validation of the protocols for PMI estimation. 


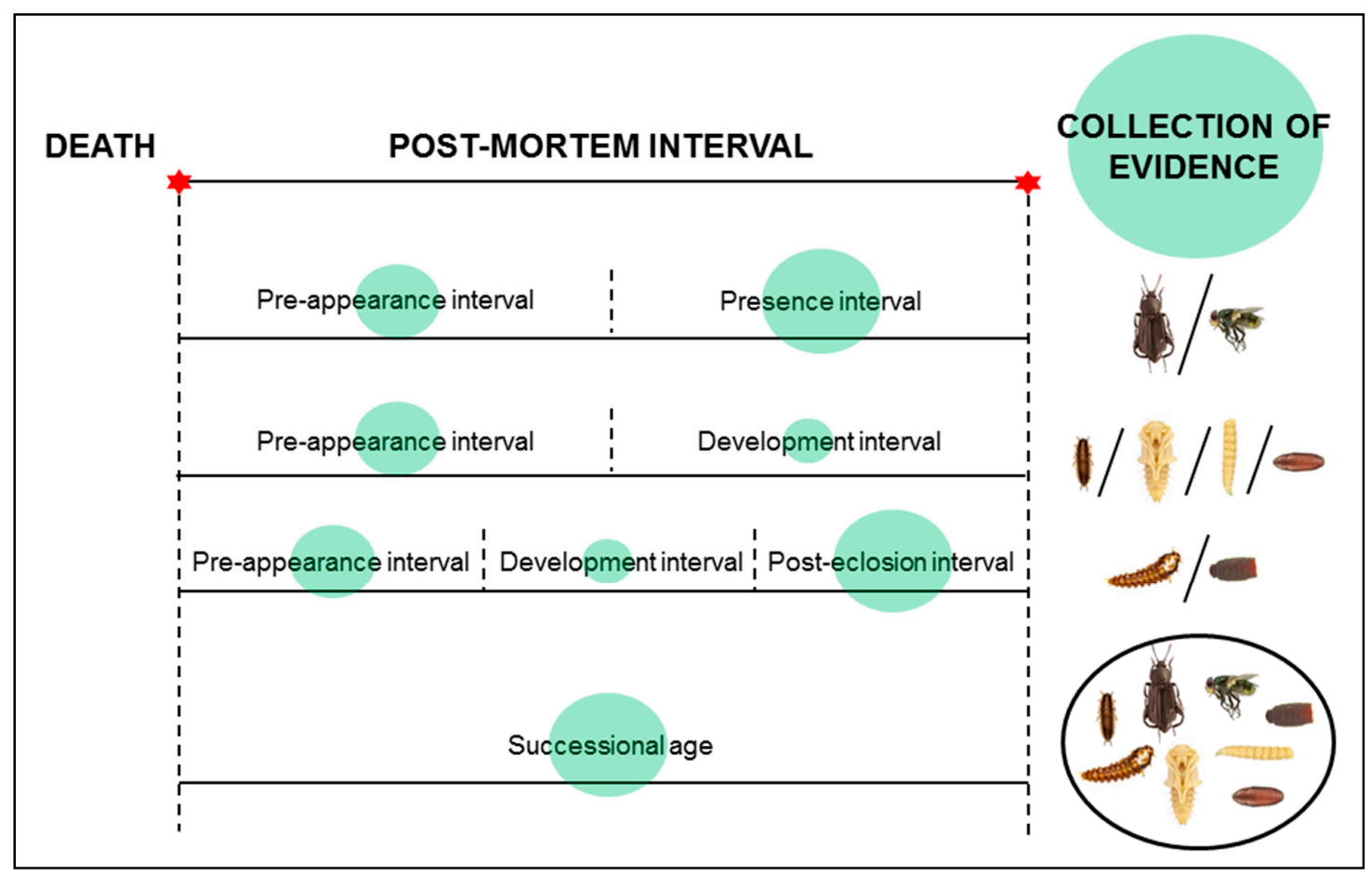

Figure 1. Sources of inaccuracy in the estimation of the post-mortem interval (PMI) based on insect evidence. Green circles represent the sources, their size represents importance of the sources. Pictures of insects were made by Anna Mądra-Bielewicz (Poznań, Poland).

\section{Collection of Insect Evidence}

Errors in the collection of insect evidence are certainly among the most important sources of the inaccuracy in PMI estimation. Death scene samples frequently misrepresent cadaver entomofauna. However, it is difficult to discern how bad these samples usually are and what the consequences of sampling errors are for the estimation of PMI. In most cases insects are collected by law enforcement officers or medical examiners, and rarely by entomologists. In a recent case, insects were sampled by police officers with the medical examiner and independently by entomologists, which enabled-in this paperthe comparison of samples taken by non-experts and experts [5]. The sample taken by non-experts was distinctly less diverse and did not contain insect evidence, based on which PMI has finally been estimated (see Tables 1 and 2 in [5]). If PMI was estimated in this case using only the non-expert sample, no meaningful maximum PMI would be derived, although the minimum PMI would be similar to the one estimated based on the expert sample (unpublished data). Another kind of error in the collection of evidence is the error of preservation. Insects may be preserved improperly, for example using an unsuitable preservative or a leaking container [6,7]. Such errors may limit the scope of possible analyses and in extreme cases may even destroy the evidence. Although there are no surveys of errors in the collection of insect evidence, I think that most experts share the opinion that insect samples frequently misrepresent cadaver entomofauna or are preserved improperly. We should therefore discuss whether our guidelines for the collection of evidence are truly fit-for-purpose.

Guidelines for the collection of insect evidence state that death scene samples should accurately represent cadaver entomofauna, i.e., all life stages of each important species that inhabit a cadaver should be represented in the sample [8-10]. Cadaver entomofauna may be very diverse and abundant, consisting of many life stages from many species, some in very large numbers. However, to estimate PMI only a small part of it is necessary. Usually, we choose the most developmentally advanced life stage of the most successionally advanced species, and even if the PMI estimate is based on a larger number of taxa, this is usually no more than two or three [11]. Therefore, in most cases a representative sample is redundant, 
and for this reason we should reshape guidelines for the collection of insect evidence and abandon our commitment to the true representativeness of death scene samples. I believe it is possible to develop guidelines that are user-friendly, quick to implement and that yield more fit-for-purpose samples, i.e., the most developmentally and successionally advanced insects only (Table 1). Insects are usually collected by the law enforcement officers with basic skills in entomology, whereas guidelines for the collection of insect evidence are usually addressed to entomologists. Therefore, we should provide guidelines for nonentomologists that specify what insect evidence they should look for and where it can be found, with pictures of the evidence and related preservation protocols.

Table 1. A sketch of guidelines for the collection of insect evidence on a death scene. To make them useful to nonentomologists, they should be combined with pictures of insect evidence and protocols suitable for the preservation of particular pieces of evidence.

\begin{tabular}{|c|c|c|}
\hline \multirow{2}{*}{ State of a Cadaver } & \multicolumn{2}{|c|}{ Insect Evidence } \\
\hline & What to Look For & Where to Look For \\
\hline Relatively fresh & Eggs or larvae of flies & $\begin{array}{l}\text { Natural orifices (particularly of the } \\
\text { head), wounds }\end{array}$ \\
\hline $\begin{array}{l}\text { Signs of putrefaction (bloating, } \\
\text { marbling, etc.) }\end{array}$ & Larvae of flies & $\begin{array}{l}\text { Natural orifices, wounds, interface } \\
\text { cadaver/ground }\end{array}$ \\
\hline $\begin{array}{l}\text { Signs of active decay (large masses of } \\
\text { insect larvae, stench of decay, leakage of } \\
\text { decomposition fluids, etc.) }\end{array}$ & $\begin{array}{l}\text { 1. Larvae (particularly post-feeding) } \\
\text { of flies } \\
\text { 2. Larvae of beetles }\end{array}$ & $\begin{array}{l}\text { 1. Larval masses, the surface of soil } \\
\text { (outdoor scenarios) or the floor (indoor } \\
\text { scenarios) in the vicinity of a cadaver } \\
\text { 2. Larval masses, clothes and cadaver } \\
\text { surface, the soil in the vicinity of a } \\
\text { cadaver (outdoor scenarios, soil samples } \\
\text { are recommended), the floor in the } \\
\text { vicinity of a cadaver (indoor scenarios) }\end{array}$ \\
\hline $\begin{array}{l}\text { Signs of advanced decay (exposed bones; } \\
\text { greasy by-products of active decay, } \\
\text { darkening of the remaining skin, etc.) }\end{array}$ & $\begin{array}{l}\text { 1. Puparia (full and empty) of flies } \\
\text { 2. Larvae and pupae of beetles } \\
\text { 3. Larvae of late-colonizing flies (e.g., } \\
\text { skipper flies) }\end{array}$ & $\begin{array}{l}\text { 1. The soil in the vicinity of a cadaver } \\
\text { (outdoor scenarios, soil samples are } \\
\text { recommended), the floor (under carpets } \\
\text { or furniture) in the vicinity of a cadaver } \\
\text { (indoor scenarios), pockets and foldings } \\
\text { of clothes, cadaver surface (all scenarios) } \\
\text { 2. Larval masses, clothes and cadaver } \\
\text { surface, the soil in the vicinity of a } \\
\text { cadaver (outdoor scenarios, soil samples } \\
\text { are recommended), the floor in the } \\
\text { vicinity of a cadaver (indoor scenarios) } \\
\text { 3. Larval masses, the surface of soil } \\
\text { (outdoor scenarios) or the floor (indoor } \\
\text { scenarios) in the vicinity of a cadaver }\end{array}$ \\
\hline $\begin{array}{l}\text { Signs of minimal insect infestation (e.g., } \\
\text { massive putrefaction or mummification) }\end{array}$ & All types of insect evidence & $\begin{array}{l}\text { Natural orifices, wounds, clothes and } \\
\text { cadaver surface, the soil (outdoor } \\
\text { scenarios) or the floor (indoor scenarios) } \\
\text { in the vicinity of a cadaver }\end{array}$ \\
\hline
\end{tabular}

\section{Insect Development}

Most frequently, forensic entomologists estimate the age of immature insects collected on a death scene and use this information as the minimum PMI [12]. The reference developmental data for the species that was collected on a death scene is necessary for such estimation. Because developmental data may vary between geographical populations of insects, it is recommended to use reference data from the closest population [10,13-15]. Although there is constant progress in this field, with new species and populations gaining developmental data, still much research needs to be done. A review of developmental datasets available for insect species colonizing cadavers in central Europe reveals that 
among the most extensively researched are cosmopolitan species that colonize cadavers shortly after death and that were frequently reported from indoor cases (Table 2). Although several important species have many datasets (e.g., Lucilia sericata or Calliphora vicina), there are still species that regularly breed in cadavers but for which no dataset has been published (e.g., Lucilia caesar, Hydrotaea ignava or Necrobia violacea) or only single datasets are available (e.g., Stearibia nigriceps, Necrodes littoralis, Omosita colon or Necrobia rufipes). These species should become the hot taxa for forensic entomology research in Europe. The understudied species ought to be identified also for other geographical regions.

Another point that needs our attention is the lack of standards and guidelines for developmental studies in forensic entomology. Several elements of the protocol for such studies were found to affect the quality of the resultant developmental data [16-19]. In addition, there is unnecessary variation in the type of development data provided and the way they are presented in publications. Standard research protocols emerge in mature sciences and I feel it is time to start this discussion in forensic entomology.

Table 2. Developmental datasets available for the species that breed in large vertebrate cadavers in central Europe (species list compiled based on [20-25]).

\begin{tabular}{|c|c|c|c|c|}
\hline Family & Species & $\begin{array}{c}\text { Number of Published } \\
\text { Datasets }\end{array}$ & Country of a Population's Origin & References \\
\hline \multirow[t]{7}{*}{ Calliphoridae } & Calliphora vicina & 18 & US,AT,GB,RU,CA,DE,IT,EG & [26-43] \\
\hline & Calliphora vomitoria & 7 & US,GB,RU,DE & {$[26,29,31,33,37,44,45]$} \\
\hline & Chrysomya albiceps & 9 & $\mathrm{BR}, \mathrm{RU}, \mathrm{AT}, \mathrm{ZA}, \mathrm{CO}, \mathrm{IR}, \mathrm{EG}$ & {$[14,26,39,46-51]$} \\
\hline & Lucilia caesar & - & - & - \\
\hline & Lucilia sericata & 27 & US,FI,IT,GB,RU,CA,AT,CO,IR,EG,TR,FR & $-28,30,31,33,36,48,52-70]$ \\
\hline & Phormia regina & 7 & US,RU,CA,MX & {$[26-28,31,71-73]$} \\
\hline & Protophormia terraenovae & 7 & US,GB,RU,AT,CA & {$[26,31,33,44,74-76]$} \\
\hline \multirow[t]{2}{*}{ Sarcophagidae } & Sarcophaga argyrostoma & 3 & AT,DE,TR & {$[29,77,78]$} \\
\hline & Sarcophaga caerulescens & - & - & - \\
\hline \multirow[t]{3}{*}{ Muscidae } & Hydrotaea dentipes & - & - & - \\
\hline & Hydrotaea ignava & - & - & - \\
\hline & Hydrotaea pilipes & - & - & - \\
\hline \multirow[t]{3}{*}{ Fanniidae } & Fannia canicularis & 2 & US,PL & {$[79,80]$} \\
\hline & Fannia scalaris & - & - & - \\
\hline & Fannia leucosticta & - & - & - \\
\hline Piophilidae & Stearibia nigriceps & 1 & RU & [26] \\
\hline \multirow[t]{3}{*}{ Silphidae } & Necrodes littoralis & 2 & PL & {$[81,82]$} \\
\hline & Thanatophilus rugosus & 1 & $\mathrm{DZ}$ & [83] \\
\hline & Thanatophilus sinuatus & 1 & $\mathrm{CZ}$ & [84] \\
\hline \multirow[t]{3}{*}{ Histeridae } & Margarinotus brunneus & - & - & - \\
\hline & Saprinus planiusculus & - & - & - \\
\hline & Saprinus semistriatus & - & - & - \\
\hline \multirow[t]{3}{*}{ Staphylinidae } & Aleochara curtula & - & - & - \\
\hline & Creophilus maxillosus & 5 & US,CN,PL & [85-89] \\
\hline & Philonthus politus & - & - & - \\
\hline \multirow[t]{3}{*}{ Dermestidae } & Dermestes frischii & 3 & GB,ES,IT & [90-92] \\
\hline & Dermestes lardarius & 2 & GB & {$[93,94]$} \\
\hline & Dermestes murinus & - & - & - \\
\hline Nitidulidae & Omosita colon & 1 & $\mathrm{CN}$ & [95] \\
\hline \multirow[t]{2}{*}{ Cleridae } & Necrobia rufipes & 1 & $\mathrm{CN}$ & [96] \\
\hline & Necrobia violacea & - & - & - \\
\hline Pteromalidae & Nasonia vitripennis & 5 & $\mathrm{AT}, \mathrm{US}, \mathrm{AU}, \mathrm{CN}, \mathrm{BR}$ & [97-101] \\
\hline
\end{tabular}

AT-Austria, AU-Australia, BR-Brazil, CA-Canada, CN-China, CO-Colombia, CZ-Czech Republic, DE-Germany, DZ-Algeria, EC-Ecuador, EG_Egypt, ES-Spain, FI_Finland, FR_France, GB-United Kingdom, IR-Iran, IT-Italy, KR-Republic of Korea, MX-Mexico, PL-Poland, RU-Russian Federation, TR-Turkey, US-United States and ZA-South Africa. 


\section{Insect Succession}

There are several forensic reasons to study insect succession on cadavers. First, these studies yield inventories of carrion insects for habitats and geographical locations that form a starting point for any further research in forensic entomology. Such inventories were published for many habitats and locations around the world (recently reviewed in [102]), but there are still white spots on this map.

Second, succession studies provide reference data on the pre-appearance interval (PAI) and the presence interval (PI) of particular insect taxa. Such data are essential to use insects that colonize cadavers late in decomposition, as their PAI may be longer than the development interval, and to get meaningful PMI it may be necessary to combine insect age with the PAI $[5,11,103]$. PAI may also support estimates of maximum PMI when insect evidence is absent $[104,105]$. PAI may be estimated using the temperature models for PAI [106]. However, such models are available only for some taxa, and for several important taxa (e.g., blow flies) PAI may not be estimated using the temperature data $[107,108]$. In such cases, insect succession studies with animal cadavers (preferably large pigs [102]) yield the best PAI reference data (e.g., average seasonal PAIs). As for the PI, it has a more complex causal background than PAI, its predictions are inherently related with larger inaccuracy (Figure 1) and currently it may be approximated only based on the reference data from succession studies. Although in some habitats and locations robust PAI or PI datasets are available for many taxa, usually there is shortage of such data (Table 3). In particular, indoor habitats need more attention. Therefore, pig decomposition studies to yield PAI and PI data of forensically relevant insects should be one of the priority research areas in forensic entomology.

Third, decomposition experiments using pig cadavers may be useful to validate the PMI estimation protocols [109]. Such experiments are especially suitable as proof-ofconcept studies or initial validation studies [102]. Although validation of new methods is a priority in forensic sciences [110], datasets on the performance of insect-based methods for PMI are very limited. Validation using pig cadavers (ultimately also human cadavers [102]) should be another primary research area in forensic entomology (Section 6 of this article).

There are guidelines for decomposition studies in forensic entomology [102,111-115]. Still, however, more standardization is necessary, particularly in terms of the sampling frequency, insect identifications and the presentation of the results (summarized in [116]). We need to remember that PAI and PI data for particular taxa are necessary when results of the study are to be used for the estimation of PMI. Therefore, the data for immature insects should be prioritized. When only a few cadavers were used, a daily occurrence matrix may be the best choice to present the results in a forensically useful way $[117,118]$. When more cadavers were investigated, it may be necessary to present insect occurrences in a synthetic way, but still raw data from individual cadavers (or seasonal averages) should be given on the PAI and PI of particular insect taxa (e.g., [119]).

Table 3. Datasets on the pre-appearance interval (PAI) and the presence interval (PI) of the species that breed in large vertebrate cadavers in central Europe (species list compiled based on [20-25]). I reviewed datasets derived from experiments performed in Europe and on pig cadavers only.

\begin{tabular}{|c|c|c|c|c|c|}
\hline \multirow{2}{*}{ Family } & \multirow{2}{*}{ Species } & \multicolumn{2}{|r|}{ PAI } & \multirow[t]{2}{*}{$\begin{array}{l}\text { PI-Seasonal Data } \\
\text { (Country/Habitat/Season/Stage) }\end{array}$} & \multirow[t]{2}{*}{ References } \\
\hline & & Temperature Model & $\begin{array}{c}\text { Seasonal Data } \\
\text { (Country/Habitat/Season/Stage) }\end{array}$ & & \\
\hline Calliphoridae & Calliphora vicina & - & $\begin{array}{c}\mathrm{PL} / \mathrm{F} / \mathrm{S} / \mathrm{A}, \mathrm{L} 1 \\
\mathrm{IT} / \mathrm{Ou} / \mathrm{u} / \mathrm{Au}, \mathrm{W} / \mathrm{A} \\
\mathrm{AT} / \mathrm{Ou} / \mathrm{u} / \mathrm{S}, \mathrm{Su} / \mathrm{A} \\
\mathrm{PT} / \mathrm{Ou} / \mathrm{u} / \mathrm{S}, \mathrm{Su}, \mathrm{Au}, \mathrm{W} / \mathrm{A} \\
\mathrm{PT} / \mathrm{Ou} / \mathrm{u} / \mathrm{S}, \mathrm{Au}, \mathrm{W} / \mathrm{O}, \mathrm{L} 1, \mathrm{P} \\
\mathrm{ES} / \mathrm{I} / \mathrm{S}, \mathrm{Su}, \mathrm{Au}, \mathrm{W} / \mathrm{O}\end{array}$ & $\begin{array}{c}\mathrm{PL} / \mathrm{F} / \mathrm{S} / \mathrm{A}, \mathrm{L} \\
\mathrm{IT} / \mathrm{Ou} / \mathrm{u} / \mathrm{Au}, \mathrm{W} / \mathrm{A} \\
\mathrm{AT} / \mathrm{Ou} / \mathrm{u} / \mathrm{S}, \mathrm{Su} / \mathrm{A} \\
\mathrm{PT} / \mathrm{Ou} / \mathrm{u} / \mathrm{S}, \mathrm{Su}, \mathrm{Au}, \mathrm{W} / \mathrm{A} \\
\mathrm{PT} / \mathrm{Ou} / \mathrm{u} / \mathrm{S}, \mathrm{Au}, \mathrm{W} / \mathrm{E}, \mathrm{L}, \mathrm{P} \\
\mathrm{ES} / \mathrm{I} / \mathrm{S}, \mathrm{Su}, \mathrm{Au}, \mathrm{W} / \mathrm{E}\end{array}$ & [22,119-122] \\
\hline
\end{tabular}


Table 3. Cont.

\begin{tabular}{|c|c|c|c|c|c|}
\hline \multirow{2}{*}{ Family } & \multirow{2}{*}{ Species } & \multicolumn{2}{|r|}{ PAI } & \multirow[t]{2}{*}{$\begin{array}{c}\text { PI-Seasonal Data } \\
\text { (Country/Habitat/Season/Stage) }\end{array}$} & \multirow[t]{2}{*}{ References } \\
\hline & & Temperature Model & $\begin{array}{c}\text { Seasonal Data } \\
\text { (Country/Habitat/Season/Stage) }\end{array}$ & & \\
\hline & Calliphora vomitoria & - & $\begin{array}{c}\mathrm{PL} / \mathrm{F} / \mathrm{S}, \mathrm{Su}, \mathrm{Au} / \mathrm{A}, \mathrm{L} 1, \mathrm{~L} 3 \\
\mathrm{IT} / \mathrm{Ou} / \mathrm{u} / \mathrm{Au}, \mathrm{W} / \mathrm{A} \\
\mathrm{AT} / \mathrm{Ou} / \mathrm{u} / \mathrm{S} / \mathrm{A} \\
\mathrm{PT} / \mathrm{Ou} / \mathrm{u} / \mathrm{S}, \mathrm{Su}, \mathrm{Au}, \mathrm{W} / \mathrm{A} \\
\mathrm{PT} / \mathrm{Ou} / \mathrm{u} / \mathrm{S}, \mathrm{W} / \mathrm{O}, \mathrm{L} 1, \mathrm{P} \\
\mathrm{ES} / \mathrm{I} / \mathrm{S} / \mathrm{O}\end{array}$ & $\begin{array}{c}\mathrm{PL} / \mathrm{F} / \mathrm{S}, \mathrm{Su}, \mathrm{Au} / \mathrm{A}, \mathrm{L} \\
\mathrm{IT} / \mathrm{Ou} / \mathrm{u} / \mathrm{Au}, \mathrm{W} / \mathrm{A} \\
\mathrm{AT} / \mathrm{Ou} / \mathrm{u} / \mathrm{S} / \mathrm{A} \\
\mathrm{PT} / \mathrm{Ou} / \mathrm{u} / \mathrm{S}, \mathrm{Su}, \mathrm{Au}, \mathrm{W} / \mathrm{A} \\
\mathrm{PT} / \mathrm{Ou} / \mathrm{u} / \mathrm{S}, \mathrm{W} / \mathrm{E}, \mathrm{L}, \mathrm{P} \\
\mathrm{ES} / \mathrm{I} / \mathrm{S} / \mathrm{E}\end{array}$ & {$[22,25,119-123]$} \\
\hline & Chrysomya albiceps & - & $\begin{array}{c}\mathrm{IT} / \mathrm{Ou} / \mathrm{u} / \mathrm{Su}, \mathrm{Au} / \mathrm{A} \\
\mathrm{AT} / \mathrm{Ou} / \mathrm{u} / \mathrm{Su} / \mathrm{A} \\
\mathrm{PT} / \mathrm{Ou} / \mathrm{u} / \mathrm{Su}, \mathrm{Au} / \mathrm{A} \\
\mathrm{PT} / \mathrm{Ou} / \mathrm{u} / \mathrm{Su}, \mathrm{Au} / \mathrm{O}, \mathrm{L} 1, \mathrm{P} \\
\mathrm{ES} / \mathrm{I} / \mathrm{S}, \mathrm{Su}, \mathrm{Au} / \mathrm{O}\end{array}$ & $\begin{array}{c}\mathrm{IT} / \mathrm{Ou} / \mathrm{u} / \mathrm{Su}, \mathrm{Au} / \mathrm{A} \\
\mathrm{AT} / \mathrm{Ou} / \mathrm{u} / \mathrm{Su} / \mathrm{A} \\
\mathrm{PT} / \mathrm{Ou} / \mathrm{u} / \mathrm{Su}, \mathrm{Au} / \mathrm{A} \\
\mathrm{PT} / \mathrm{Ou} / \mathrm{u} / \mathrm{Su}, \mathrm{Au} / \mathrm{E}, \mathrm{L}, \mathrm{P} \\
\mathrm{ES} / \mathrm{I} / \mathrm{S}, \mathrm{Su}, \mathrm{Au} / \mathrm{E}\end{array}$ & {$[22,120-122]$} \\
\hline & Lucilia caesar & - & $\begin{array}{c}\mathrm{PL} / \mathrm{Ou} / \mathrm{r} / \mathrm{S}, \mathrm{Su} / \mathrm{A}, \mathrm{L} 3 \\
\mathrm{PL} / \mathrm{F} / \mathrm{S}, \mathrm{Su}, \mathrm{Au} / \mathrm{A}, \mathrm{L} 1, \mathrm{~L} 3 \\
\mathrm{IT} / \mathrm{Ou} / \mathrm{u} / \mathrm{Su}, \mathrm{Au}, \mathrm{W} / \mathrm{A} \\
\mathrm{PT} / \mathrm{Ou} / \mathrm{u} / \mathrm{S}, \mathrm{Su}, \mathrm{Au} / \mathrm{A} \\
\mathrm{PT} / \mathrm{Ou} / \mathrm{u} / \mathrm{S}, \mathrm{Su}, \mathrm{Au} / \mathrm{O}, \mathrm{L} 1, \mathrm{P}\end{array}$ & $\begin{array}{c}\mathrm{PL} / \mathrm{F} / \mathrm{S}, \mathrm{Su}, \mathrm{Au} / \mathrm{A}, \mathrm{L} \\
\mathrm{IT} / \mathrm{Ou} / \mathrm{u} / \mathrm{Su}, \mathrm{Au}, \mathrm{W} / \mathrm{A} \\
\mathrm{PT} / \mathrm{Ou} / \mathrm{u} / \mathrm{S}, \mathrm{Su}, \mathrm{Au} / \mathrm{A} \\
\mathrm{PT} / \mathrm{Ou} / \mathrm{u} / \mathrm{S}, \mathrm{Su}, \mathrm{Au} / \mathrm{E}, \mathrm{L}, \mathrm{P}\end{array}$ & {$[21,25,119-121,123]$} \\
\hline & Lucilia sericata & - & $\begin{array}{c}\mathrm{PL} / \mathrm{Ou} / \mathrm{r} / \mathrm{S}, \mathrm{Su} / \mathrm{A} \\
\mathrm{IT} / \mathrm{Ou} / \mathrm{u} / \mathrm{Su}, \mathrm{Au}, \mathrm{W} / \mathrm{A} \\
\mathrm{PT} / \mathrm{Ou} / \mathrm{u} / \mathrm{S}, \mathrm{Su}, \mathrm{Au} / \mathrm{A} \\
\mathrm{PT} / \mathrm{Ou} / \mathrm{u} / \mathrm{Au} / \mathrm{O}, \mathrm{L} 1, \mathrm{P} \\
\mathrm{ES} / \mathrm{I} / \mathrm{S}, \mathrm{Su}, \mathrm{Au} / \mathrm{O}\end{array}$ & $\begin{array}{c}\mathrm{IT} / \mathrm{Ou} / \mathrm{u} / \mathrm{Su}, \mathrm{Au}, \mathrm{W} / \mathrm{A} \\
\mathrm{PT} / \mathrm{Ou} / \mathrm{u} / \mathrm{S}, \mathrm{Su}, \mathrm{Au} / \mathrm{A} \\
\mathrm{PT} / \mathrm{Ou} / \mathrm{u} / \mathrm{Au} / \mathrm{E}, \mathrm{L}, \mathrm{P} \\
\mathrm{ES} / \mathrm{I} / \mathrm{S}, \mathrm{Su}, \mathrm{Au} / \mathrm{E}\end{array}$ & {$[21,120-122]$} \\
\hline & Phormia regina & A & $\begin{array}{c}\mathrm{PL} / \mathrm{Ou} / \mathrm{r} / \mathrm{S}, \mathrm{Su} / \mathrm{A} \\
\mathrm{PL} / \mathrm{F} / \mathrm{S}, \mathrm{Su}, \mathrm{Au} / \mathrm{A}, \mathrm{L} 1 \\
\mathrm{AT} / \mathrm{Ou} / \mathrm{u} / \mathrm{S}, \mathrm{Su} / \mathrm{A} \\
\mathrm{PL} / \mathrm{F} / \mathrm{S}, \mathrm{Su} / \mathrm{L} 3\end{array}$ & $\begin{array}{l}\mathrm{PL} / \mathrm{F} / \mathrm{S}, \mathrm{Su}, \mathrm{Au} / \mathrm{A}, \mathrm{L} \\
\mathrm{AT} / \mathrm{Ou} / \mathrm{u} / \mathrm{S}, \mathrm{Su} / \mathrm{A}\end{array}$ & {$[21,22,25,107,119,123]$} \\
\hline & Protophormia terraenovae & - & $\mathrm{AT} / \mathrm{Ou} / \mathrm{u} / \mathrm{S}, \mathrm{Su} / \mathrm{A}$ & $\mathrm{AT} / \mathrm{Ou} / \mathrm{u} / \mathrm{S}, \mathrm{Su} / \mathrm{A}$ & [22] \\
\hline \multirow[t]{2}{*}{ Sarcophagidae } & Sarcophaga argyrostoma & - & - & - & - \\
\hline & Sarcophaga caerulescens & - & - & - & - \\
\hline \multirow[t]{3}{*}{ Muscidae } & Hydrotaea dentipes & A & $\begin{array}{c}\mathrm{PL} / \mathrm{F} / \mathrm{S}, \mathrm{Su}, \mathrm{Au} / \mathrm{A} \\
\mathrm{PT} / \mathrm{Ou} / \mathrm{u} / \mathrm{S} / \mathrm{A} \\
\mathrm{PL} / \mathrm{F} / \mathrm{S}, \mathrm{Su} / \mathrm{L} 1\end{array}$ & $\begin{array}{c}\mathrm{PL} / \mathrm{F} / \mathrm{S}, \mathrm{Su}, \mathrm{Au} / \mathrm{A} \\
\mathrm{PT} / \mathrm{Ou} / \mathrm{u} / \mathrm{S} / \mathrm{A} \\
\mathrm{PL} / \mathrm{F} / \mathrm{S}, \mathrm{Su} / \mathrm{L}\end{array}$ & {$[25,107,119,121,123]$} \\
\hline & Hydrotaea ignava & A & $\begin{array}{c}\mathrm{PL} / \mathrm{Ou} / \mathrm{r} / \mathrm{S}, \mathrm{Su} / \mathrm{A}, \mathrm{L} 3 \\
\mathrm{PL} / \mathrm{F} / \mathrm{S}, \mathrm{Su}, \mathrm{Au} / \mathrm{A} \\
\mathrm{PT} / \mathrm{Ou} / \mathrm{u} / \mathrm{S}, \mathrm{Su}, \mathrm{Au} / \mathrm{A} \\
\mathrm{PL} / \mathrm{F} / \mathrm{S}, \mathrm{Su} / \mathrm{L} 1 \\
\mathrm{PL} / \mathrm{F} / \mathrm{Su} / \mathrm{L} 3\end{array}$ & $\begin{array}{c}\mathrm{PL} / \mathrm{F} / \mathrm{S}, \mathrm{Su}, \mathrm{Au} / \mathrm{A} \\
\mathrm{PT} / \mathrm{Ou} / \mathrm{u} / \mathrm{S}, \mathrm{Su}, \mathrm{Au} / \mathrm{A} \\
\mathrm{PL} / \mathrm{F} / \mathrm{S}, \mathrm{Su} / \mathrm{L}\end{array}$ & {$[21,25,107,119,121]$} \\
\hline & Hydrotaea pilipes & - & $\begin{array}{l}\mathrm{PL} / \mathrm{Ou} / \mathrm{r} / \mathrm{S}, \mathrm{Su} / \mathrm{A} \\
\mathrm{PL} / \mathrm{F} / \mathrm{S}, \mathrm{Su}, \mathrm{Au} / \mathrm{A}\end{array}$ & $\mathrm{PL} / \mathrm{F} / \mathrm{Su}, \mathrm{Au} / \mathrm{A}$ & {$[21,25,123]$} \\
\hline \multirow[t]{3}{*}{ Fanniidae } & Fannia canicularis & - & $\mathrm{IT} / \mathrm{Ou} / \mathrm{u} / \mathrm{Au}, \mathrm{W} / \mathrm{A}$ & $\mathrm{IT} / \mathrm{Ou} / \mathrm{u} / \mathrm{Au}, \mathrm{W} / \mathrm{A}$ & [120] \\
\hline & Fannia scalaris & - & - & - & - \\
\hline & Fannia leucosticta & - & - & - & - \\
\hline Piophilidae & Stearibia nigriceps & $\mathrm{A}, \mathrm{O}$ & $\begin{array}{c}\mathrm{PL} / \mathrm{Ou} / \mathrm{r} / \mathrm{S}, \mathrm{Su} / \mathrm{A}, \mathrm{L} 3 \\
\mathrm{PL} / \mathrm{F} / \mathrm{S}, \mathrm{Su}, \mathrm{Au} / \mathrm{A}, \mathrm{L} 1 \\
\mathrm{IT} / \mathrm{Ou} / \mathrm{u} / \mathrm{Au} / \mathrm{A} \\
\mathrm{PT} / \mathrm{Ou} / \mathrm{u} / \mathrm{S}, \mathrm{Su}, \mathrm{Au} / \mathrm{A} \\
\mathrm{PT} / \mathrm{Ou} / \mathrm{u} / \mathrm{Su} / \mathrm{E} \\
\mathrm{PT} / \mathrm{Ou} / \mathrm{u} / \mathrm{S}, \mathrm{Su}, \mathrm{Au} / \mathrm{L} 1, \mathrm{P} \\
\mathrm{PL} / \mathrm{F} / \mathrm{S}, \mathrm{Su} / \mathrm{L} 3\end{array}$ & $\begin{array}{c}\mathrm{PL} / \mathrm{F} / \mathrm{S}, \mathrm{Su}, \mathrm{Au} / \mathrm{A}, \mathrm{L} \\
\mathrm{IT} / \mathrm{Ou} / \mathrm{u} / \mathrm{Au} / \mathrm{A} \\
\mathrm{PT} / \mathrm{Ou} / \mathrm{u} / \mathrm{S}, \mathrm{Su}, \mathrm{Au} / \mathrm{A} \\
\mathrm{PT} / \mathrm{Ou} / \mathrm{u} / \mathrm{Su} / \mathrm{E} \\
\mathrm{PT} / \mathrm{Ou} / \mathrm{u} / \mathrm{S}, \mathrm{Su}, \mathrm{Au} / \mathrm{L}, \mathrm{P}\end{array}$ & {$[21,25,107,119-121,123]$} \\
\hline \multirow[t]{3}{*}{ Silphidae } & Necrodes littoralis & A,L1 & $\begin{array}{l}\mathrm{PL} / \mathrm{Ou} / \mathrm{r} / \mathrm{S}, \mathrm{Su} / \mathrm{A}, \mathrm{L} 1 \\
\mathrm{PL} / \mathrm{F} / \mathrm{S}, \mathrm{Su}, \mathrm{Au} / \mathrm{A}, \mathrm{L} 1\end{array}$ & $\mathrm{PL} / \mathrm{F} / \mathrm{S}, \mathrm{Su}, \mathrm{Au} / \mathrm{A}, \mathrm{L}$ & {$[21,25,103,119,123,124]$} \\
\hline & Thanatophilus rugosus & - & $\begin{array}{c}\mathrm{PL} / \mathrm{F} / \mathrm{S}, \mathrm{Su}, \mathrm{Au} / \mathrm{A} \\
\mathrm{IT} / \mathrm{F} / \mathrm{W} / \mathrm{A} \\
\mathrm{PL} / \mathrm{Ou} / \mathrm{r} / \mathrm{S} / \mathrm{L} 3\end{array}$ & $\begin{array}{l}\mathrm{PL} / \mathrm{F} / \mathrm{Su}, \mathrm{Au} / \mathrm{A} \\
\mathrm{IT} / \mathrm{F} / \mathrm{W} / \mathrm{A} \\
\mathrm{PL} / \mathrm{Ou} / \mathrm{r} / \mathrm{S} / \mathrm{L} 3\end{array}$ & {$[25,120,123,125]$} \\
\hline & Thanatophilus sinuatus & A,L1 & $\begin{array}{c}\mathrm{PL} / \mathrm{Ou} / \mathrm{r} / \mathrm{S}, \mathrm{Su} / \mathrm{a} \\
\mathrm{PL} / \mathrm{F} / \mathrm{S}, \mathrm{Su}, \mathrm{Au} / \mathrm{A} \\
\mathrm{IT} / \mathrm{Ou} / \mathrm{u} / \mathrm{W} / \mathrm{A} \\
\mathrm{PT} / \mathrm{Ou} / \mathrm{u} / \mathrm{S}, \mathrm{Au}, \mathrm{W} / \mathrm{A} \\
\mathrm{PL} / \mathrm{Ou} / \mathrm{r} / \mathrm{S} / \mathrm{L} 3\end{array}$ & $\begin{array}{c}\mathrm{PL} / \mathrm{F} / \mathrm{S}, \mathrm{Su}, \mathrm{Au} / \mathrm{A} \\
\mathrm{IT} / \mathrm{Ou} / \mathrm{u} / \mathrm{W} / \mathrm{A} \\
\mathrm{PT} / \mathrm{Ou} / \mathrm{u} / \mathrm{S}, \mathrm{Au}, \mathrm{W} / \mathrm{A} \\
\mathrm{PL} / \mathrm{Ou} / \mathrm{r} / \mathrm{S} / \mathrm{L} 3\end{array}$ & {$[21,25,119,120,124-126]$} \\
\hline \multirow[t]{3}{*}{ Histeridae } & Margarinotus brunneus & A & $\begin{array}{c}\mathrm{PL} / \mathrm{Ou} / \mathrm{r} / \mathrm{S}, \mathrm{Su} / \mathrm{A} \\
\mathrm{PL} / \mathrm{F} / \mathrm{S}, \mathrm{Su} / \mathrm{A} \\
\mathrm{PT} / \mathrm{Ou} / \mathrm{u} / \mathrm{S}, \mathrm{Su}, \mathrm{Au}, \mathrm{W} / \mathrm{A}\end{array}$ & $\begin{array}{c}\mathrm{PL} / \mathrm{F} / \mathrm{S}, \mathrm{Su} / \mathrm{A} \\
\mathrm{PT} / \mathrm{Ou} / \mathrm{u} / \mathrm{S}, \mathrm{Su}, \mathrm{Au}, \mathrm{W} / \mathrm{A}\end{array}$ & {$[21,25,119,124,126]$} \\
\hline & Saprinus planiusculus & A & $\mathrm{PL} / \mathrm{F} / \mathrm{S} / \mathrm{A}$ & $\mathrm{PL} / \mathrm{F} / \mathrm{S} / \mathrm{A}$ & {$[119,124]$} \\
\hline & Saprinus semistriatus & A & $\begin{array}{l}\mathrm{PL} / \mathrm{Ou} / \mathrm{r} / \mathrm{S}, \mathrm{Su} / \mathrm{A} \\
\mathrm{PL} / \mathrm{F} / \mathrm{S}, \mathrm{Su}, \mathrm{Au} / \mathrm{A}\end{array}$ & $\mathrm{PL} / \mathrm{F} / \mathrm{S}, \mathrm{Su}, \mathrm{Au} / \mathrm{A}$ & {$[21,25,119,123,124]$} \\
\hline
\end{tabular}


Table 3. Cont

\begin{tabular}{|c|c|c|c|c|c|}
\hline \multirow{2}{*}{ Family } & \multirow{2}{*}{ Species } & \multicolumn{2}{|r|}{ PAI } & \multirow[t]{2}{*}{$\begin{array}{l}\text { PI-Seasonal Data } \\
\text { (Country/Habitat/Season/Stage) }\end{array}$} & \multirow[t]{2}{*}{ References } \\
\hline & & Temperature Model & $\begin{array}{c}\text { Seasonal Data } \\
\text { (Country/Habitat/Season/Stage) }\end{array}$ & & \\
\hline \multirow[t]{3}{*}{ Staphylinidae } & Aleochara curtula & - & $\begin{array}{c}\mathrm{PL} / \mathrm{F} / \mathrm{S}, \mathrm{Su} / \mathrm{A} \\
\mathrm{IT} / \mathrm{Ou} / \mathrm{u} / \mathrm{W} / \mathrm{A}\end{array}$ & $\mathrm{IT} / \mathrm{Ou} / \mathrm{u} / \mathrm{W} / \mathrm{A}$ & {$[25,120]$} \\
\hline & Creophilus maxillosus & $\mathrm{A}, \mathrm{L} 1$ & $\begin{array}{c}\mathrm{PL} / \mathrm{Ou} / \mathrm{r} / \mathrm{S}, \mathrm{Su} / \mathrm{A}, \mathrm{L} 1 \\
\mathrm{PL} / \mathrm{F} / \mathrm{S}, \mathrm{Su}, \mathrm{Au} / \mathrm{A}, \mathrm{L} 1 \\
\mathrm{IT} / \mathrm{Ou} / \mathrm{u} / \mathrm{Au}, \mathrm{W} / \mathrm{A} \\
\mathrm{PT} / \mathrm{Ou} / \mathrm{u} / \mathrm{S}, \mathrm{Su}, \mathrm{Au}, \mathrm{W} / \mathrm{A}\end{array}$ & $\begin{array}{c}\mathrm{PL} / \mathrm{F} / \mathrm{S}, \mathrm{Su}, \mathrm{Au} / \mathrm{A}, \mathrm{L} \\
\mathrm{IT} / \mathrm{Ou} / \mathrm{u} / \mathrm{Au}, \mathrm{W} / \mathrm{A} \\
\mathrm{PT} / \mathrm{Ou} / \mathrm{u} / \mathrm{S}, \mathrm{Su}, \mathrm{Au}, \mathrm{W} / \mathrm{A}\end{array}$ & $\begin{array}{c}{[21,25,119,120,123,124,} \\
126,127]\end{array}$ \\
\hline & Philonthus politus & A & $\begin{array}{l}\mathrm{PL} / \mathrm{F} / \mathrm{S}, \mathrm{Su}, \mathrm{Au} / \mathrm{A} \\
\mathrm{IT} / \mathrm{Ou} / \mathrm{u} / \mathrm{Au} / \mathrm{A}\end{array}$ & $\mathrm{IT} / \mathrm{Ou} / \mathrm{u} / \mathrm{Au} / \mathrm{A}$ & {$[25,120,124]$} \\
\hline \multirow[t]{3}{*}{ Dermestidae } & Dermestes frischii & - & $\begin{array}{c}\mathrm{PL} / \mathrm{Ou} / \mathrm{r} / \mathrm{S}, \mathrm{Su} / \mathrm{A}, \mathrm{L} 1 \\
\mathrm{PT} / \mathrm{Ou} / \mathrm{u} / \mathrm{S}, \mathrm{Su}, \mathrm{Au} / \mathrm{A}\end{array}$ & $\mathrm{PT} / \mathrm{Ou} / \mathrm{u} / \mathrm{S}, \mathrm{Su}, \mathrm{Au} / \mathrm{A}$ & {$[21,126]$} \\
\hline & Dermestes lardarius & - & - & - & - \\
\hline & Dermestes murinus & - & $\begin{array}{l}\mathrm{PL} / \mathrm{F} / \mathrm{S}, \mathrm{Su}, \mathrm{Au} / \mathrm{A} \\
\mathrm{PL} / \mathrm{F} / \mathrm{S} / \mathrm{Lm}\end{array}$ & $\mathrm{PL} / \mathrm{F} / \mathrm{Su}, \mathrm{Au} / \mathrm{A}$ & {$[25,123]$} \\
\hline Nitidulidae & Omosita colon & - & - & - & - \\
\hline \multirow[t]{2}{*}{ Cleridae } & Necrobia rufipes & $\mathrm{A}$ & $\begin{array}{c}\mathrm{IT} / \mathrm{Ou} / \mathrm{u} / \mathrm{Su}, \mathrm{W} / \mathrm{A} \\
\mathrm{PT} / \mathrm{Ou} / \mathrm{u} / \mathrm{Su}, \mathrm{Au} / \mathrm{A}\end{array}$ & $\begin{array}{c}\mathrm{IT} / \mathrm{Ou} / \mathrm{u} / \mathrm{Su}, \mathrm{W} / \mathrm{A} \\
\mathrm{PT} / \mathrm{Ou} / \mathrm{u} / \mathrm{Su}, \mathrm{Au} / \mathrm{A}\end{array}$ & {$[120,124,126]$} \\
\hline & Necrobia violacea & A & $\begin{array}{c}\mathrm{PL} / \mathrm{Ou} / \mathrm{r} / \mathrm{S}, \mathrm{Su} / \mathrm{A} \\
\mathrm{PL} / \mathrm{F} / \mathrm{S}, \mathrm{Su} / \mathrm{A} \\
\mathrm{PT} / \mathrm{Ou} / \mathrm{u} / \mathrm{S}, \mathrm{Su}, \mathrm{Au}, \mathrm{W} / \mathrm{A} \\
\mathrm{PL} / \mathrm{F} / \mathrm{S} / \mathrm{L3}\end{array}$ & $\begin{array}{c}\mathrm{PT} / \mathrm{Ou} / \mathrm{u} / \mathrm{S}, \mathrm{Su}, \mathrm{Au}, \mathrm{W} / \mathrm{A} \\
\mathrm{PL} / \mathrm{F} / \mathrm{S} / \mathrm{L} 3\end{array}$ & {$[21,25,119,124,126]$} \\
\hline Pteromalidae & Nasonia vitripennis & - & $\mathrm{AT} / \mathrm{Ou} / \mathrm{u} / \mathrm{S} / \mathrm{A}$ & $\mathrm{AT} / \mathrm{Ou} / \mathrm{u} / \mathrm{S} / \mathrm{A}$ & {$[22]$} \\
\hline
\end{tabular}

\section{Temperature Conditions}

The succession and development of insects on cadavers is largely dependent on the temperature $[124,128,129]$. When estimating PMI from insect succession or development, it is necessary to reconstruct temperature conditions. The accuracy of the PMI estimation depends largely on the accuracy of the reconstructed temperature conditions. This source of error is one of the most important.

Forensic entomologists frequently use temperature data from the local weather stations. Weather station temperatures can be corrected to adjust them to the peculiarities of a death scene [130-134]. Such corrections are based on the regression analysis between recordings made on a death scene and recordings from the station and for this reason they may be unfeasible [135]. Moreover, some authors indicate that the correction protocol has uncertain benefits for the accuracy of PMI estimation [135,136]. From the other side, there are robust experimental data indicating that the protocol improves the death scene temperatures [130,132-134]. It was found beneficial in casework, as well [5,132], although it was used infrequently [134]. The protocol may be impractical and its use may have a minor risk of deteriorating the death scene temperatures; however, it is the best tool we have and we should try to use it more frequently, particularly on outdoor death scenes. We need to remember that the protocol makes the weather station temperatures closer to the cadaver's ambient temperatures only. Therefore, the corrected temperatures may still be far from the true temperatures experienced by the insects, because the protocol accounts for peculiarities of a death scene in terms of the factors that affect ambient air temperature only. In order to take into account other important factors a different approach is needed.

Some authors modelled temperature conditions in parked vehicles [137], containers [138] or specific urban and semi-natural habitats (e.g., cellars, attics or trailers) [139]. A model was also derived to extract heat profiles representing the temperatures experienced by insect populations growing on cadavers [140]. Charabidze and Hedouin [135] developed an algorithm to correct temperatures through a qualitative analysis of thermal-specific aspects of the case. The analysis consisted of six stages, starting from the conditions on a 
cadaver and moving towards the outside of the body. This research area is growing and both quantitative and qualitative approaches may be useful here.

The last factor that needs much more of our attention is the insect-driven thermogenesis. It has been discovered and extensively studied in aggregations of blow fly larvae [141-152]. Recently, insect-driven thermogenesis has been also reported for carrion beetles Necrodes littoralis L. (Silphidae), with evidence that heat is produced within the feeding matrix, which is formed by adult and larval beetles through spreading their exudates over the cadaver surface [153]. Thermogenesis in larval aggregations may be more common among carrion insects, and because it may substantially shorten the development interval, it should be factored when reconstructing temperature conditions $[151,153]$.

When large aggregations of fly larvae (with elevated temperature) are present on a cadaver, Charabidze and Hedouin [135] suggest to use the minimum development time for the feeding stage of each species. Unfortunately, minimum times needed to reach the post-feeding phase in large aggregations of larvae are not available for any species. Accordingly, it may be tempting to use minimum development times from the laboratory development studies, as there are many such datasets (Table 2). However, in such studies minimum development times are recorded at high and constant temperatures that may be suboptimal for the insects. Experiments using the tracking of blow fly larvae within aggregations indicated that they have a strong preference for the hottest part of the aggregation [154]. This finding prompted the authors to state that the maximum temperatures of the aggregation represent the actual temperatures experienced by the larvae [154]. More recent data demonstrated that larvae continuously move between the periphery and the inside of the aggregation, with individual larvae spending from 16 to $68 \%$ (mean $43 \%$ ) of their time at the aggregation periphery [155]. The periphery has a lower temperature than the inside of the aggregation [154]. For this reason, the heat gain of individual larvae may be smaller than if they were feeding for the whole time in the hottest part of the aggregation. The maximum temperature of the aggregation probably overestimates the true temperatures experienced by the larvae. Perhaps the heat benefit of the aggregated larvae is somehow related to the temperatures selected by the larvae along a thermal gradient $[143,154,156]$. Further research using tracking techniques to monitor heat benefits and the development time of individual larvae within large aggregations will be necessary to find the minimum development times or the optimal temperatures for the larvae that develop in an aggregation.

\section{Challenging Evidence}

All insect evidence can be challenging in some cases, and some types are always challenging. The puparia of flies and pupae of beetles are informative pieces of insect evidence, particularly on decomposed cadavers [5,11]. However, they are difficult to identify and it is difficult to estimate their age.

The identification of insect evidence is a necessary first step in any analysis. Significant progress has been recently made in this field, with several forensically important fly taxa gaining excellent identification keys for adult insects [13,157-161] and larvae [162-164]. Puparia should be the next step. Although some groups of carrion flies have useful descriptions of puparia [165], there is no forensically useful key for this type of insect evidence in any family of flies. This area is much less developed in the case of the forensically important beetles. There is just a single identification key for the larvae of beetles that colonize cadavers [166] and a single key for the adult carrion beetles (Silphidae) that frequent cadavers [167]. Although some descriptions of larval identification features have been published for forensically important species $[168,169]$, this group needs more attention. Otherwise, we will still have to base our identifications on the taxonomic references that may be inaccessible to forensic entomologists with no experience in beetle taxonomy.

It is difficult to estimate the age of the fixed puparia of flies and pupae of beetles. The most promising techniques for aging such evidence consist of the qualitative morphological analyses of the intra-puparial forms of the flies $[30,35,36]$. Intra-puparial development has 
been documented for many forensically important species [35,65,78,170-175]. Although these techniques have obvious advantages (e.g., they cover most of the intra-puparial development, they are generally non-destructive, low-cost and they need a stereomicroscope only), they have also important disadvantages (e.g., they are qualitative in nature and therefore less accurate and they are also impractical due to the need to have an expert knowledge in the intra-puparial morphology) [82]. Recently, a simple-to-use technique has been developed for aging pupae of the carrion beetle Necrodes littoralis by means of the quantification of the eye-background contrast, with very encouraging results of the initial validation [82]. Similar quantitative techniques should be developed in other forensically important insects.

Empty puparia (i.e., hardened outer shells that remain upon the completion of immature development of some flies) are frequently collected on cadavers with long PMI, and their examination may provide an estimate of the minimum PMI [176]. This type of insect evidence poses specific difficulties. When estimating minimum PMI based on the empty puparium, it is necessary to take the post-eclosion interval (PEI) into account. The interval starts when an adult fly emerges from the puparium and ends when the empty puparium is being collected. PEI may be longer than the minimum PMI estimated based on the puparium. Although techniques to estimate PEI are being developed [177-179], they are far from the implementation to forensic casework. In a recent PMI simulation study, seasonal patterns of changes in PMI following various PEIs were revealed for the empty puparia of two species of flies, demonstrating that the simulation studies may guide estimation of the minimum PMI based on such challenging evidence [176].

\section{Validation of the PMI Estimation Protocols}

Forensic entomologists developed several methods for the estimation of PMI based on insect development $[26,41,180-182]$ or succession $[103,105,115,117,118,128,183]$. As there are contemporary reviews of these methods $[1,184]$, in this article I focus only on their validation (Table 4). Validation of a protocol for the estimation of PMI is of key importance, as it may demonstrate that the protocol provides robust evidence when used in a forensic context. Validation studies may also provide PMI errors that could be used to present a PMI estimate as a meaningful interval. Sometimes entomologists provide point estimates for PMI (e.g., [185,186]). The inaccuracy of the PMI estimate that usually has many and diverse sources, but which is inherently related to every analysis of insect evidence, should be explicit in casework. This may be accomplished by providing ranges for PMI. Therefore, an interval estimate for PMI should be a standard way to present the results of the insect evidence analysis. If we knew robust errors, they could be used to transform any PMI estimate (a point or a range) into a highly informative interval that takes into account all sources of inaccuracy. The error of estimation is the difference between the estimated and true PMI, expressed as a percentage of the true or estimated PMI (hereafter error I and II). If such errors were calculated for a reliable sample of PMI estimations, i.e., a large sample of forensic case reports with known true PMI or a large sample of PMI estimations for experimentally used human cadavers, they might robustly approximate the accuracy of the PMI estimation protocol in a forensic context. I believe that such errors could also yield a truly informative evaluation of the uncertainty in PMI estimates in casework.

Most of the validation studies in forensic entomology were proof-of-assumptions or proof-of-concept studies (Table 4). Experiments fully validating the estimation protocols were rare. Only a few such datasets have been published; most used pig cadavers and were replicated moderately, at most. Human cadavers in anthropology research facilities (i.e., body farms) could be used more extensively for that purpose. The estimation of PMI for such cadavers using mock crime scenarios could provide robust validation data. This research design is surprisingly underutilised at body farms.

Similarly, validations using casework data were infrequent (Table 4). In order to use the casework data for the validation, a true PMI needs to be specified based on a confession or a witness statement about when the victim was last seen alive, or other non-insect 
evidence. Although the non-insect evidence only approximates the true PMI sensu stricto, this is the only way to use casework data for the validation. However, published case reports rarely provide information on the true PMI sensu largo. In order to calculate the errors of insect-based protocols for PMI, I analyzed relevant case reports where the PMI was estimated based on insect development (Table 5) and separately based on insect succession (Table 6). Due to the imperfections of the data used, resultant errors need to be treated with caution. They are only rough approximations of the true errors of the insect-based protocols for PMI.

Table 4. Validation of the protocols for the estimation of PMI based on insect evidence.

\begin{tabular}{|c|c|c|c|c|c|}
\hline \multirow{2}{*}{ Type of the Validation } & \multirow{2}{*}{ Aims } & \multicolumn{2}{|c|}{ Development-Based Protocols } & \multicolumn{2}{|c|}{ Succession-Based Protocols } \\
\hline & & Number of Studies & References & Number of Studies & References \\
\hline $\begin{array}{l}\text { Proof-of-assumptions } \\
\text { study }{ }^{1}\end{array}$ & $\begin{array}{l}\text { Testing validity of the } \\
\text { assumptions that are at } \\
\text { the root of the protocol }\end{array}$ & 26 & $\begin{array}{c}{[14,17-19,27,29,30,34,41,55-} \\
57,61,144,145,176,187-196]\end{array}$ & 56 & $\begin{array}{c}{[20,21,24,25,103,107,113,119,} \\
\quad 122,124,127,128,197-240]\end{array}$ \\
\hline Proof-of-concept study ${ }^{1}$ & $\begin{array}{l}\text { Testing validity of the } \\
\text { protocol as used in a } \\
\text { simplified setting }\end{array}$ & 12 & {$[30,73,81,82,87-89,241-245]$} & 3 & {$[103,127,128]$} \\
\hline $\begin{array}{l}\text { Experimental validation } \\
\text { with non-human } \\
\text { cadavers }\end{array}$ & $\begin{array}{l}\text { Testing validity of the } \\
\text { protocol as used for } \\
\text { non-human cadavers in } \\
\text { an experimental setting }\end{array}$ & 6 & {$[109,241,246-249]$} & 6 & {$[105,106,183,249-251]$} \\
\hline $\begin{array}{l}\text { Experimental validation } \\
\text { using human cadavers }\end{array}$ & $\begin{array}{l}\text { Testing validity of the } \\
\text { protocol as used for } \\
\text { human cadavers in an } \\
\text { experimental setting }\end{array}$ & 0 & & 1 & [183] \\
\hline $\begin{array}{l}\text { Validation using } \\
\text { casework data }^{1}\end{array}$ & $\begin{array}{l}\text { Testing validity of the } \\
\text { protocol as used in } \\
\text { forensic casework }\end{array}$ & 7 & {$[46,118,182,185,252-254]$} & 6 & {$[5,108,118,186,255,256]$} \\
\hline
\end{tabular}

There were surprisingly large differences between the cases. Errors I (differences between the true and estimated PMI expressed as the percentage of the true PMI) ranged from 0 to $83 \%$ for the development-based estimates (Table 5) and from 2 to $43 \%$ for the succession-based estimates (Table 6). Surprisingly, average errors were larger for the development-based estimates (22.3\%) than the succession-based estimates (13.4\%). Although the average difference between the true and estimated PMI was almost four times lower for the development-based estimation than the succession-based estimation (1.5 and 5.6 days respectively, Tables 5 and 6), the latter type of the estimation was usually used for cadavers with a much larger PMI (Table 6); therefore, it had lower errors, which are relative values. Differences between the true and estimated PMI increased with the increase in the true PMI, and this relationship was particularly apparent when plotted for the development-based estimates (Figure 2).

Summarizing, the protocols for the estimation of PMI based on insect evidence usually lack errors and their validity has been rather poorly demonstrated in a true forensic context. Therefore, validation studies using pig or human cadavers and casework data should be prioritized in forensic entomology. I think this is our greatest challenge. 


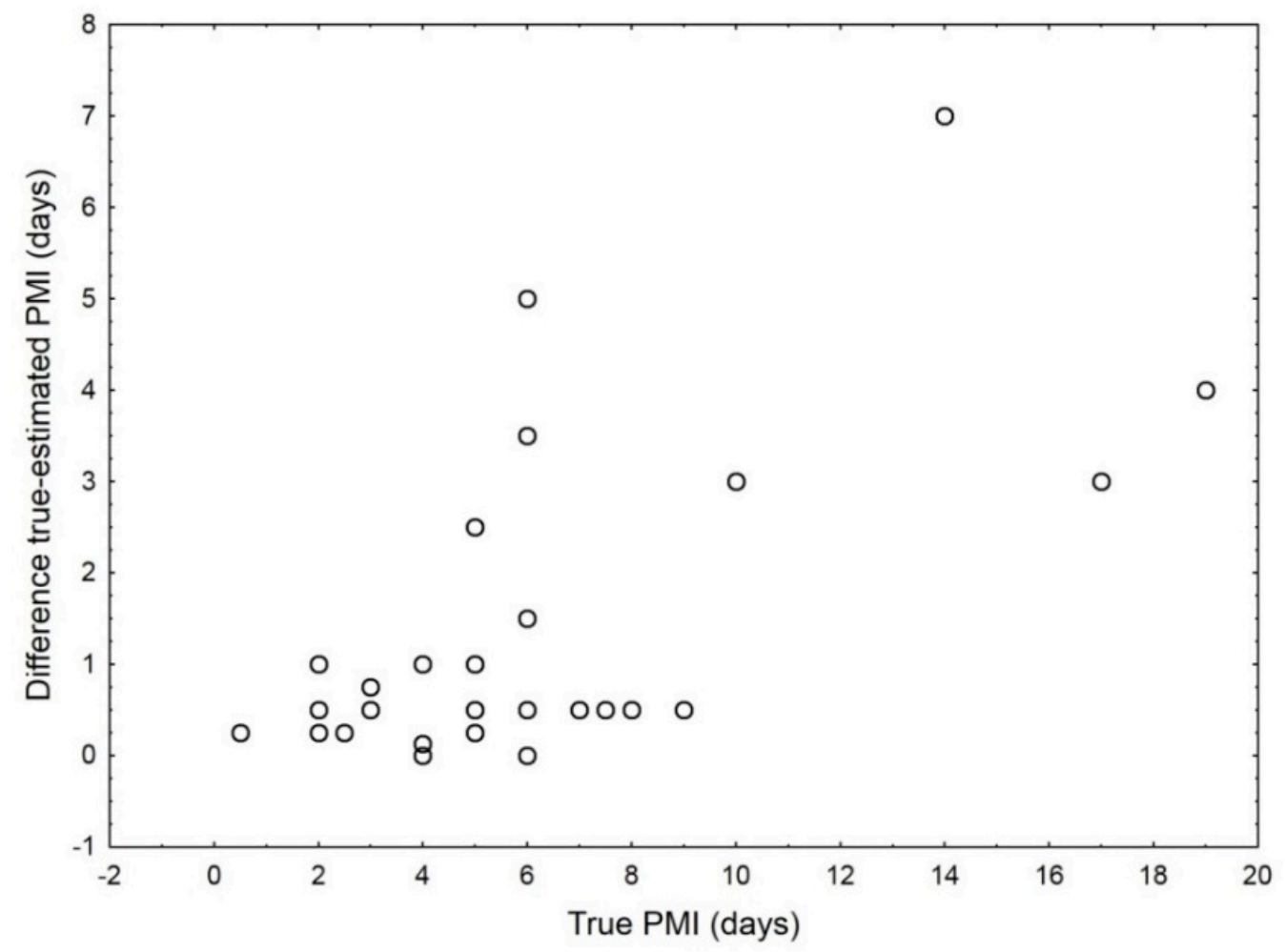

Figure 2. Differences between the true and estimated PMI plotted against the true PMI for the estimations based on insect development that were referenced in Table 5.

Table 5. Errors of the protocols for the estimation of PMI based on insect development.

\begin{tabular}{|c|c|c|c|c|c|c|c|c|c|c|}
\hline \multirow[t]{2}{*}{ Reference } & \multirow[t]{2}{*}{$\mathbf{N}$} & \multicolumn{2}{|c|}{$\begin{array}{l}\text { True PMI }{ }^{1} \\
\text { (days) }\end{array}$} & \multicolumn{2}{|c|}{$\begin{array}{c}\text { Difference } \\
\text { True-Estimated PMI } \\
2 \\
\text { (days) }\end{array}$} & \multicolumn{2}{|c|}{$\begin{array}{l}\text { Error } I^{3} \\
\quad(\%)\end{array}$} & \multicolumn{2}{|c|}{$\begin{array}{l}\text { Error II } \\
\quad(\%)\end{array}$} & \multirow[t]{2}{*}{ Remarks } \\
\hline & & Mean & Range & Mean & Range & Mean & Range & Mean & Range & \\
\hline $\begin{array}{l}\text { Goff et al., } \\
1988 \text { [252] }\end{array}$ & 2 & 5.5 & $5-6$ & 0.375 & $0.25-0.5$ & 6.65 & $5-8.3$ & 6.95 & $4.8-9.1$ & - \\
\hline $\begin{array}{l}\text { Kashyap, Pillay, } \\
1989 \text { [185] }\end{array}$ & 16 & 4.9 & $0.5-9$ & 0.438 & $0-1$ & 13.74 & $0-50$ & 11.65 & $0-33.3$ & $\begin{array}{l}\text { No mention } \\
\text { of tempera- } \\
\text { ture } \\
\text { data }\end{array}$ \\
\hline $\begin{array}{c}\text { Grassberger et al., } \\
2003 \text { [46] }\end{array}$ & 1 & 17 & - & 3 & - & 17.65 & - & 20 & - & - \\
\hline $\begin{array}{c}\text { Reibe et al., } 2010 \\
\text { [182] }\end{array}$ & 1 & 4 & - & 0.125 & - & 3.125 & - & 3.03 & - & - \\
\hline $\begin{array}{l}\text { Pohjoismäki et al., } \\
2010 \text { [253] }\end{array}$ & 7 & 10.6 & 5-19 & 4.57 & $2.5-7$ & 48.96 & $21.1-83.3$ & 144.2 & $26.7-500$ & $\begin{array}{c}\text { Single } \\
\text { average } \\
\text { tempera- } \\
\text { ture } \\
\text { assumed in } \\
\text { all cases } \\
\left(24^{\circ} \mathrm{C}\right)\end{array}$ \\
\hline $\begin{array}{l}\text { Bugelli et al., } 2015 \\
\text { [254] }\end{array}$ & 4 & 4.0 & $2-6$ & 0.94 & $0.5-1.5$ & 23.75 & $20-25$ & 31.25 & $25-33$ & - \\
\hline
\end{tabular}

$\mathrm{N}$ - a number of PMI estimations in a dataset. ${ }^{1}$ PMI determined based on non-insect evidence (a confession, a witness statement about when the victim was last seen alive, etc.). ${ }^{2}$ An absolute difference between the true PMI and the PMI estimated based on insect development. When the estimated PMI was presented as an interval, I calculated absolute differences between the true PMI and the lower and upper limit of the estimated interval and then averaged them to get the difference between the true and estimated PMI. ${ }^{3}$ Error $\mathrm{I}=\left(\right.$ the difference between the true and estimated PMI/true PMI) $\times 100 .{ }^{4}$ Error II $=($ the difference between the true and estimated PMI/estimated PMI) $\times 100$. When the estimated PMI was presented as an interval, a midpoint of the interval was used in denominator. 
Table 6. Errors of the protocols for the estimation of PMI based on insect succession.

\begin{tabular}{|c|c|c|c|c|c|c|c|}
\hline Reference & $\mathbf{N}$ & $\begin{array}{l}\text { True PMI }{ }^{1} \\
\quad \text { (days) }\end{array}$ & $\begin{array}{l}\text { Estimated } \\
\text { PMI (days) }\end{array}$ & $\begin{array}{c}\text { Difference } \\
\text { True- } \\
\text { Estimated } \\
\text { PMI }^{2} \text { (days) }\end{array}$ & Error $I^{3}(\%)$ & Error II ${ }^{4}(\%)$ & Remarks \\
\hline Goff et al., 1986 [256] & 1 & 20 & $19-20$ & 0.5 & 2.5 & 2.6 & - \\
\hline Goff and Odom, 1987 [186] & 1 & 53 & $\geq 52$ & 1 & 1.9 & 1.9 & - \\
\hline Goff and Flynn, 1991 [255] & 1 & 38 & $34-39$ & 2.5 & 6.6 & 6.8 & - \\
\hline \multirow{2}{*}{ Schoenly et al., 1996 [118] } & \multirow{2}{*}{2} & 11 & $10.5-11$ & 0.25 & 2.3 & 2.3 & \multirow[t]{2}{*}{-} \\
\hline & & 36 & $34-36$ & 1 & 2.8 & 2.9 & \\
\hline Archer, 2014 [108] & 1 & 21 & $16-34$ & 9 & 42.9 & 36 & - \\
\hline $\begin{array}{c}\text { Matuszewski and } \\
\text { Mądra-Bielewicz, } 2019 \text { [5] }\end{array}$ & 1 & 72 & $30-64$ & 25 & 34.7 & 53.2 & $\begin{array}{l}\text { Less reliable } \\
\text { true PMI }\end{array}$ \\
\hline
\end{tabular}

$\mathrm{N}$-a number of PMI estimations in a dataset. ${ }^{1}$ PMI determined based on non-insect evidence (a confession, a witness statement about when the victim was last seen alive, etc.). ${ }^{2}$ An absolute difference between the true PMI and the PMI estimated based on insect succession. When the estimated PMI was presented as an interval, I calculated absolute differences between the true PMI and the lower and upper limit of the estimated interval and then averaged them to get the difference between the true and estimated PMI. ${ }^{3}$ Error $\mathrm{I}=($ the difference between the true and estimated PMI/true PMI) $\times 100 .{ }^{4}$ Error II $=$ (the difference between true and estimated PMI/estimated PMI) $\times 100$. When the estimated PMI was presented as an interval, a midpoint of the interval was used in denominator.

\section{Conclusions}

Although the set of challenges elucidated in this article is somehow subjective, I believe that most forensic entomologists would construct similar sets. Some challenges should focus more of our attention, with priority for the resultant research. This applies, in particular, to the validation research, as well as to development and succession research. Studies on thermogenesis in larval aggregations on cadavers should be prioritized as well. There are also highly important challenges of educational and promotional nature. Although we should look for more optimal guidelines for insect sampling on a death scene, and this is a scientific task, improvement in the samples taken by a law enforcement personnel depends equally or even more on the promotion of forensic entomology among its end-users and on the education of the officers or medical examiners that collect insect evidence on death scenes.

Funding: This research received no external funding.

Acknowledgments: I thank the anonymous reviewers for their comments that helped to improve the manuscript. Thanks are also extended to Anna Mądra-Bielewicz (Poznań, Poland) for pictures of insects that were used in Figure 1.

Conflicts of Interest: The author declares no conflict of interest.

\section{References}

1. Villet, M.H.; Amendt, J. Advances in entomological methods for death time estimation. In Forensic Pathology Reviews; Turk, E.E., Ed.; Springer: Berlin/Heidelberg, Germany, 2011; pp. 213-237.

2. Catts, E.P.; Goff, M.L. Forensic entomology in criminal investigations. Annu. Rev. Entomol. 1992, 37, 253-272. [CrossRef]

3. Lei, G.; Liu, F.; Liu, P.; Zhou, Y.; Jiao, T.; Dang, Y.-H. A bibliometric analysis of forensic entomology trends and perspectives worldwide over the last two decades (1998-2017). Forensic Sci. Int. 2019, 295, 72-82. [CrossRef]

4. Tomberlin, J.K.; Benbow, M.E. Forensic Entomology: International Dimensions and Frontiers; CRC Press: Boca Raton, FL, USA, 2015.

5. Matuszewski, S.; Mądra-Bielewicz, A. Post-mortem interval estimation based on insect evidence in a quasi-indoor habitat. Sci. Justice 2019, 59, 109-115. [CrossRef]

6. Sanford, M.R.; Pechal, J.L.; Tomberlin, J.K. Rehydration of forensically important larval Diptera specimens. J. Med. Entomol. 2011, 48, 118-125. [CrossRef]

7. Mądra-Bielewicz, A.; Frątczak-Łagiewska, K.; Matuszewski, S. Blowfly puparia in a hermetic container: Survival under decreasing oxygen conditions. Forensic Sci. Med. Pathol. 2017, 13, 328-335. [CrossRef]

8. Sanford, M.R.; Byrd, J.H.; Tomberlin, J.K.; Wallace, J.R. Entomological evidence collection methods: American Board of Forensic Entomology approved protocols. In Forensic Entomology Utility of Arthropods in Legal Investigations; Byrd, J.H., Tomberlin, J.K., Eds.; CRC Press: Boca Raton, FL, USA, 2019; pp. 63-86. 
9. Lord, W.D.; Burger, J.F. Collection and preservation of forensically important entomological materials. J. Forensic Sci. 1983, 28, 936-944. [CrossRef]

10. Amendt, J.; Campobasso, C.P.; Gaudry, E.; Reiter, C.; LeBlanc, H.N.; Hall, M.J. Best practice in forensic entomology—Standards and guidelines. Int. J. Leg. Med. 2007, 121, 90-104. [CrossRef]

11. Bajerlein, D.; Taberski, D.; Matuszewski, S. Estimation of postmortem interval (PMI) based on empty puparia of Phormia regina (Meigen) (Diptera: Calliphoridae) and third larval stage of Necrodes littoralis (L.) (Coleoptera: Silphidae) —Advantages of using different PMI indicators. J. Forensic Leg. Med. 2018, 55, 95-98. [CrossRef]

12. Amendt, J.; Richards, C.S.; Campobasso, C.P.; Zehner, R.; Hall, M.J. Forensic entomology: Applications and limitations. Forensic Sci. Med. Pathol. 2011, 7, 379-392. [CrossRef]

13. Greenberg, B.; Kunich, J.C. Entomology and the Law: Flies as Forensic Indicators; Cambridge University Press: Cambridge, UK, 2002; p. 306.

14. Richards, C.S.; Paterson, I.D.; Villet, M.H. Estimating the age of immature Chrysomya albiceps (Diptera: Calliphoridae), correcting for temperature and geographical latitude. Int. J. Leg. Med. 2008, 122, 271-279. [CrossRef]

15. Owings, C.G.; Spiegelman, C.; Tarone, A.M.; Tomberlin, J.K. Developmental variation among Cochliomyia macellaria Fabricius (Diptera: Calliphoridae) populations from three ecoregions of Texas, USA. Int. J. Leg. Med. 2014, 128, 709-717. [CrossRef]

16. Midgley, J.M.; Villet, M.H. Effect of the killing method on post-mortem change in length of larvae of Thanatophilus micans (Fabricius 1794) (Coleoptera: Silphidae) stored in 70\% ethanol. Int. J. Leg. Med. 2009, 123, 103-108. [CrossRef]

17. Richards, C.S.; Villet, M.H. Factors affecting accuracy and precision of thermal summation models of insect development used to estimate post-mortem intervals. Int. J. Leg. Med. 2008, 122, 401-408. [CrossRef]

18. Richards, C.S.; Villet, M.H. Data quality in thermal summation development models for forensically important blowflies. Med. Vet. Entomol. 2009, 23, 269-276. [CrossRef]

19. Fratczak-Łagiewska, K.; Matuszewski, S. The quality of developmental reference data in forensic entomology: Detrimental effects of multiple, in vivo measurements in Creophilus maxillosus L.(Coleoptera: Staphylinidae). Forensic Sci. Int. 2019, 298, 316-322. [CrossRef]

20. Matuszewski, S.; Bajerlein, D.; Konwerski, S.; Szpila, K. Insect succession and carrion decomposition in selected forests of Central Europe. Part 2: Composition and residency patterns of carrion fauna. Forensic Sci. Int. 2010, 195, 42-51. [CrossRef]

21. Matuszewski, S.; Frątczak, K.; Konwerski, S.; Bajerlein, D.; Szpila, K.; Jarmusz, M.; Szafałowicz, M.; Grzywacz, A.; Mądra, A. Effect of body mass and clothing on carrion entomofauna. Int. J. Leg. Med. 2016, 130, 221-232. [CrossRef]

22. Grassberger, M.; Frank, C. Initial study of arthropod succession on pig carrion in a central European urban habitat. J. Med. Entomol. 2004, 41, 511-523. [CrossRef]

23. Anton, E.; Niederegger, S.; Beutel, R.G. Beetles and flies collected on pig carrion in an experimental setting in Thuringia and their forensic implications. Med. Vet. Entomol. 2011, 25, 353-364. [CrossRef]

24. Feddern, N.; Mitchell, E.A.; Amendt, J.; Szelecz, I.; Seppey, C.V. Decomposition and insect colonization patterns of pig cadavers lying on forest soil and suspended above ground. Forensic Sci. Med. Pathol. 2019, 15, 342-351. [CrossRef]

25. Jarmusz, M.; Grzywacz, A.; Bajerlein, D. A comparative study of the entomofauna (Coleoptera, Diptera) associated with hanging and ground pig carcasses in a forest habitat of Poland. Forensic Sci. Int. 2020, 309, 110212. [CrossRef] [PubMed]

26. Marchenko, M.I. Medicolegal relevance of cadaver entomofauna for the determination of the time of death. Forensic Sci. Int. 2001, 120, 89-109. [CrossRef]

27. Greenberg, B. Flies as forensic indicators. J. Med. Entomol. 1991, 28, 565-577. [CrossRef] [PubMed]

28. Anderson, G.S. Minimum and maximum development rates of some forensically important Calliphoridae (Diptera). J. Forensic Sci. 2000, 45, 824-832. [CrossRef]

29. Niederegger, S.; Pastuschek, J.; Mall, G. Preliminary studies of the influence of fluctuating temperatures on the development of various forensically relevant flies. Forensic Sci. Int. 2010, 199, 72-78. [CrossRef]

30. Martín-Vega, D.; Simonsen, T.J.; Wicklein, M.; Hall, M.J. Age estimation during the blow fly intra-puparial period: A qualitative and quantitative approach using micro-computed tomography. Int. J. Leg. Med. 2017, 131, 1429-1448. [CrossRef]

31. Kamal, A.S. Comparative study of thirteen species of sarcosaprophagous Calliphoridae and Sarcophagidae (Diptera) I. Bionomics. Ann. Entomol. Soc. Am. 1958, 51, 261-271. [CrossRef]

32. Donovan, S.; Hall, M.; Turner, B.; Moncrieff, C. Larval growth rates of the blowfly, Calliphora vicina, over a range of temperatures. Med. Vet. Entomol. 2006, 20, 106-114. [CrossRef]

33. Davies, L.; Ratcliffe, G. Development rates of some pre-adult stages in blowflies with reference to low temperatures. Med. Vet. Entomol. 1994, 8, 245-254. [CrossRef]

34. Kaneshrajah, G.; Turner, B. Calliphora vicina larvae grow at different rates on different body tissues. Int. J. Leg. Med. 2004, 118, 242-244. [CrossRef]

35. Brown, K.; Thorne, A.; Harvey, M. Calliphora vicina (Diptera: Calliphoridae) pupae: A timeline of external morphological development and a new age and PMI estimation tool. Int. J. Leg. Med. 2015, 129, 835-850. [CrossRef] [PubMed]

36. Davies, K.; Harvey, M.L. Internal Morphological Analysis for Age Estimation of Blow Fly Pupae (Diptera: Calliphoridae) in Postmortem Interval Estimation. J. Forensic Sci. 2013, 58, 79-84. [CrossRef] [PubMed]

37. Niederegger, S.; Wartenberg, N.; Spiess, R.; Mall, G. Influence of food substrates on the development of the blowflies Calliphora vicina and Calliphora vomitoria (Diptera, Calliphoridae). Parasitol. Res. 2013, 112, 2847-2853. [CrossRef] [PubMed] 
38. Baqué, M.; Filmann, N.; Verhoff, M.A.; Amendt, J. Establishment of developmental charts for the larvae of the blow fly Calliphora vicina using quantile regression. Forensic Sci. Int. 2015, 248, 1-9. [CrossRef]

39. Salimi, M.; Rassi, Y.; Oshaghi, M.; Chatrabgoun, O.; Limoee, M.; Rafizadeh, S. Temperature requirements for the growth of immature stages of blowflies species, Chrysomya albiceps and Calliphora vicina, (Diptera: Calliphoridae) under laboratory conditions. Egypt. J. Forensic Sci. 2018, 8, 1-6. [CrossRef]

40. Defilippo, F.; Bonilauri, P.; Dottori, M. Effect of Temperature on Six Different Developmental Landmarks within the Pupal Stage of the Forensically Important Blowfly Calliphora vicina (Robineau-Desvoidy) (Diptera: Calliphoridae). J. Forensic Sci. 2013, 58, 1554-1557. [CrossRef]

41. Reiter, C. Zum wachstumsverhalten der maden der blauen schmeißfliege Calliphora vicina. Zeitschrift für Rechtsmedizin 1984, 91, 295-308. [CrossRef]

42. Hwang, C.; Turner, B. Small-scaled geographical variation in life-history traits of the blowfly Calliphora vicina between rural and urban populations. Entomol. Exp. Appl. 2009, 132, 218-224. [CrossRef]

43. Limsopatham, K.; Hall, M.J.; Zehner, R.; Zajac, B.K.; Verhoff, M.A.; Sontigun, N.; Sukontason, K.; Sukontason, K.L.; Amendt, J. A molecular, morphological, and physiological comparison of English and German populations of Calliphora vicina (Diptera: Calliphoridae). PLoS ONE 2018, 13, e0207188. [CrossRef]

44. Greenberg, B.; Tantawi, T.I. Different developmental strategies in two boreal blow flies (Diptera: Calliphoridae). J. Med. Entomol. 1993, 30, 481-484. [CrossRef]

45. Ireland, S.; Turner, B. The effects of larval crowding and food type on the size and development of the blowfly, Calliphora vomitoria. Forensic Sci. Int. 2006, 159, 175-181. [CrossRef]

46. Grassberger, M.; Friedrich, E.; Reiter, C. The blowfly Chrysomya albiceps (Wiedemann)(Diptera: Calliphoridae) as a new forensic indicator in Central Europe. Int. J. Leg. Med. 2003, 117, 75-81. [CrossRef]

47. Vélez, M.C.; Wolff, M. Rearing five species of Diptera (Calliphoridae) of forensic importance in Colombia in semicontrolled field conditions. Papéis Avulsos de Zoologia 2008, 48, 41-47. [CrossRef]

48. Shiravi, A.; Mostafavi, R.; Akbarzadeh, K.; Oshaghi, M.A. Temperature requirements of some common forensically important blow and flesh flies (Diptera) under laboratory conditions. Iran. J. Arthropod-Borne Dis. 2011, 5, 54.

49. Beuter, L.; Mendes, J. Development of Chrysomya albiceps (Wiedemann)(Diptera: Calliphoridae) in different pig tissues. Neotrop. Entomol. 2013, 42, 426-430. [CrossRef]

50. Rashed, S.S.; Yamany, A.S.; El-Basheir, Z.M.; Zaher, E.E. Influence of fluctuated room conditions on the development of the forensically important Chrysomya albiceps (Wiedemann)(Diptera: Calliphoridae). J. Adv. Med. Med. Res. 2015, 5, 1413-1421. [CrossRef]

51. Queiroz, M.M.d.C. Temperature requirements of Chrysomya albiceps (Wiedemann, 1819)(Diptera, Calliphoridae) under laboratory conditions. Memórias do Instituto Oswaldo Cruz 1996, 91, 785-788. [CrossRef]

52. Grassberger, M.; Reiter, C. Effect of temperature on Lucilia sericata (Diptera: Calliphoridae) development with special reference to the isomegalen-and isomorphen-diagram. Forensic Sci. Int. 2001, 120, 32-36. [CrossRef]

53. Tarone, A.; Picard, C.; Spiegelman, C.; Foran, D. Population and temperature effects on Lucilia sericata (Diptera: Calliphoridae) body size and minimum development time. J. Med. Entomol. 2011, 48, 1062-1068. [CrossRef]

54. Tarone, A.M.; Foran, D.R. Components of developmental plasticity in a Michigan population of Lucilia sericata (Diptera: Calliphoridae). J. Med. Entomol. 2006, 43, 1023-1033. [CrossRef] [PubMed]

55. Picard, C.J.; Deblois, K.; Tovar, F.; Bradley, J.L.; Johnston, J.S.; Tarone, A.M. Increasing precision in development-based postmortem interval estimates: What's sex got to do with it? J. Med. Entomol. 2013, 50, 425-431. [CrossRef]

56. Introna, F.; Altamura, B.M.; Dell'Erba, A.; Dattoli, V. Time since death definition by experimental reproduction of Lucilia sericata cycles in growth cabinet. J. Forensic Sci. 1989, 34, 478-480. [CrossRef]

57. Gallagher, M.B.; Sandhu, S.; Kimsey, R. Variation in Developmental Time for Geographically Distinct Populations of the Common Green Bottle Fly, Lucilia sericata (Meigen). J. Forensic Sci. 2010, 55, 438-442. [CrossRef] [PubMed]

58. Nuorteva, P. Sarcosaprophagous insects as forensic indicators. In Forensic Medicine: A Study in Trauma Environmental Hazards; Tedeschi, C.G., Eckert, W.G., Tedeschi, L.G., Eds.; W.B. Saunders Co.: Philadelphia, PA, USA, 1977; pp. $1072-1095$.

59. Ash, N.; Greenberg, B. Developmental temperature responses of the sibling species Phaenicia sericata and Phaenicia pallescens. Ann. Entomol. Soc. Am. 1975, 68, 197-200. [CrossRef]

60. Wall, R.; French, N.; Morgan, K. Effects of temperature on the development and abundance of the sheep blowfly Lucilia sericata(Diptera: Calliphoridae). Bull. Entomol. Res. 1992, 82, 125-131. [CrossRef]

61. Clark, K.; Evans, L.; Wall, R. Growth rates of the blowfly, Lucilia sericata, on different body tissues. Forensic Sci. Int. 2006, 156, 145-149. [CrossRef]

62. Rueda, L.C.; Ortega, L.G.; Segura, N.A.; Acero, V.M.; Bello, F. Lucilia sericata strain from Colombia: Experimental colonization, life tables and evaluation of two artifcial diets of the blowfy Lucilia sericata (Meigen)(Diptera: Calliphoridae), Bogotá, Colombia Strain. Biol. Res. 2010, 43, 197-203. [CrossRef]

63. Roe, A.; Higley, L.G. Development modeling of Lucilia sericata (Diptera: Calliphoridae). PeerJ 2015, 3, e803. [CrossRef]

64. El-Moaty, Z.A.; Abd Elmoneim, M.K. Developmental variation of the blow fly Lucilia sericata (Meigen, 1826)(Diptera: Calliphoridae) by different substrate tissue types. J. Asia-Pac. Entomol. 2013, 16, 297-300. [CrossRef] 
65. Karabey, T.; Sert, O. The analysis of pupal development period in Lucilia sericata (Diptera: Calliphoridae) forensically important insect. Int. J. Leg. Med. 2018, 132, 1185-1196. [CrossRef]

66. Aubernon, C.; Charabidzé, D.; Devigne, C.; Delannoy, Y.; Gosset, D. Experimental study of Lucilia sericata (Diptera Calliphoridae) larval development on rat cadavers: Effects of climate and chemical contamination. Forensic Sci. Int. 2015, 253, 125-130. [CrossRef] [PubMed]

67. Cervantès, L.; Dourel, L.; Gaudry, E.; Pasquerault, T.; Vincent, B. Effect of low temperature in the development cycle of Lucilia sericata (Meigen)(Diptera, Calliphoridae): Implications for the minimum postmortem interval estimation. Forensic Sci. Res. 2018, 3, 52-59. [CrossRef] [PubMed]

68. Pruna, W.; Guarderas, P.; Donoso, D.A.; Barragán, Á. Life cycle of Lucilia sericata (Meigen 1826) collected from Andean mountains. Neotrop. Biodivers. 2019, 5, 3-9. [CrossRef]

69. Kim, H.-C.; Kim, S.-J.; Yun, J.-E.; Jo, T.-H.; Choi, B.-R.; Park, C.-G. Development of the greenbottle blowfly, Lucilia sericata, under different temperatures. Korean J. Appl. Entomol. 2007, 46, 141-145. [CrossRef]

70. Wang, M.; Wang, Y.; Hu, G.; Wang, Y.; Xu, W.; Wu, M.; Wang, J. Development of Lucilia sericata (Diptera: Calliphoridae) Under Constant Temperatures and its Significance for the Estimation of Time of Death. J. Med. Entomol. 2020, 57, 1373-1381. [CrossRef] [PubMed]

71. Byrd, J.H.; Allen, J.C. The development of the black blow fly, Phormia regina (Meigen). Forensic Sci. Int. 2001, 120, 79-88. [CrossRef]

72. Nabity, P.; Higley, L.G.; Heng-Moss, T.M. Effects of temperature on development of Phormia regina (Diptera: Calliphoridae) and use of developmental data in determining time intervals in forensic entomology. J. Med. Entomol. 2006, 43, 1276-1286. [CrossRef]

73. Nunez-Vazquez, C.; Tomberlin, J.K.; Cantu-Sifuentes, M.; Garcia-Martinez, O. Laboratory development and field validation of Phormia regina (Diptera: Calliphoridae). J. Med. Entomol. 2013, 50, 252-260. [CrossRef]

74. Grassberger, M.; Reiter, C. Effect of temperature on development of the forensically important holarctic blow fly Protophormia terraenovae (Robineau-Desvoidy)(Diptera: Calliphoridae). Forensic Sci. Int. 2002, 128, 177-182. [CrossRef]

75. Warren, J.A.; Anderson, G.S. The development of Protophormia terraenovae (Robineau-Desvoidy) at constant temperatures and its minimum temperature threshold. Forensic Sci. Int. 2013, 233, 374-379. [CrossRef]

76. Clarkson, C.; Hobischak, N.; Anderson, G. A comparison of the development rate of Protophormia terraenovae (Robineau-Desvoidy) raised under constant and fluctuating temperature regimes. Can. Soc. Forensic Sci. J. 2004, 37, 95-101. [CrossRef]

77. Grassberger, M.; Reiter, C. Effect of temperature on development of Liopygia (= Sarcophaga) argyrostoma (Robineau-Desvoidy) (Diptera: Sarcophagidae) and its forensic implications. J. Forensic Sci. 2002, 47, 1332-1336. [CrossRef] [PubMed]

78. Sert, O.; Örsel, G.M.; Şabanoğlu, B.; Özdemir, S. A Study of the pupal developments of Sarcophaga argyrostoma (RobineauDesvoidy, 1830). Forensic Sci. Med. Pathol. 2020, 16, 12-19. [CrossRef] [PubMed]

79. Grzywacz, A. Thermal requirements for the development of immature stages of Fannia canicularis (Linnaeus)(Diptera: Fanniidae). Forensic Sci. Int. 2019, 297, 16-26. [CrossRef] [PubMed]

80. Meyer, J.A.; Mullens, B.A. Development of immature Fannia spp. (Diptera: Muscidae) at constant laboratory temperatures. J. Med. Entomol. 1988, 25, 165-171. [CrossRef] [PubMed]

81. Gruszka, J.; Matuszewski, S. Estimation of physiological age at emergence based on traits of the forensically useful adult carrion beetle Necrodes littoralis L.(Silphidae). Forensic Sci. Int. 2020, 314, 110407. [CrossRef] [PubMed]

82. Novák, M.; Fratczak-Łagiewska, K.; Mąra-Bielewicz, A.; Matuszewski, S. Eye-background contrast as a quantitative marker for pupal age in a forensically important carrion beetle Necrodes littoralis L. (Silphidae). Sci. Rep. 2020, 10, 1-12. [CrossRef]

83. Guerroudj, F.Z.; Berchi, S. Effect of temperature on the development of carrion beetle Silpha rugosa (Linnaeus, 1758) (Coleoptera: Silphidae) in Algeria. J. Entomol. Zool. Stud. 2016, 4, 920-922.

84. Montoya-Molina, S.; Jakubec, P.; Qubaiová, J.; Novák, M.; Šuláková, H.; Růžička, J. Developmental Models of the Forensically Important Carrion Beetle, Thanatophilus sinuatus (Coleoptera: Silphidae). J. Med. Entomol. 2020, in press. [CrossRef]

85. Wang, Y.; Yang, J.B.; Wang, J.F.; Li, L.L.; Wang, M.; Yang, L.J.; Tao, L.Y.; Chu, J.; Hou, Y.D. Development of the forensically important beetle Creophilus maxillosus (Coleoptera: Staphylinidae) at constant temperatures. J. Med. Entomol. 2017, 54, 281-289. [CrossRef]

86. Watson-Horzelski, E.J. Survival and time of development for Creophilus maxillosus (L.) (Coleoptera: Staphylinidae) at three constant temperatures. Coleopt. Bull. 2012, 66, 365-370. [CrossRef]

87. Fratczak-Łagiewska, K.; Grzywacz, A.; Matuszewski, S. Development and validation of forensically useful growth models for Central European population of Creophilus maxillosus L. (Coleoptera: Staphylinidae). Int. J. Leg. Med. 2020, 134, 1-15.

88. Matuszewski, S.; Frątczak-Łagiewska, K. Size at emergence improves accuracy of age estimates in forensically-useful beetle Creophilus maxillosus L. (Staphylinidae). Sci. Rep. 2018, 8, 2390. [CrossRef]

89. Frątczak-Łagiewska, K.; Matuszewski, S. Sex-specific developmental models for Creophilus maxillosus (L.) (Coleoptera: Staphylinidae): Searching for larger accuracy of insect age estimates. Int. J. Leg. Med. 2018, 132, 887-895. [CrossRef]

90. Martín-Vega, D.; Díaz-Aranda, L.M.; Baz, A.; Cifrián, B. Effect of temperature on the survival and development of three forensically relevant Dermestes species (Coleoptera: Dermestidae). J. Med. Entomol. 2017, 54, 1140-1150. [CrossRef] [PubMed]

91. Amos, T. Some laboratory observations on the rates of development, mortality and oviposition of Dermestes frischii (Kug.)(Col., Dermestidae). J. Stored Prod. Res. 1968, 4, 103-117. [CrossRef] 
92. Lambiase, S.; Murgia, G.; Sacchi, R.; Ghitti, M.; Di Lucia, V. Effects of different temperatures on the development of Dermestes Frischii and Dermestes undulatus (Coleoptera, Dermestidae): Comparison between species. J. Forensic Sci. 2018, 63, 469-473. [CrossRef] [PubMed]

93. Coombs, C. The effect of temperature and relative humidity upon the development and fecundity of Dermestes lardarius L.(Coleoptera, Dermestidae). J. Stored Prod. Res. 1978, 14, 111-119. [CrossRef]

94. Fleming, D.; Jacob, T. The influence of temperature and relative humidity upon the number and duration of larval instars in Dermestes lardarius L.(Col., Dermestidae). Entomol. Mon. Mag. 1986, 122, 43-50.

95. Wang, Y.; Wang, M.; Hu, G.; Xu, W.; Wang, Y.; Wang, J. Temperature-dependent development of Omosita colon at constant temperature and its implication for PMImin estimation. J. Forensic Leg. Med. 2020, 72, 101946. [CrossRef]

96. Hu, G.; Wang, M.; Wang, Y.; Tang, H.; Chen, R.; Zhang, Y.; Zhao, Y.; Jin, J.; Wang, Y.; Wu, M. Development of Necrobia rufipes (De Geer, 1775)(Coleoptera: Cleridae) under Constant Temperature and Its Implication in Forensic Entomology. Forensic Sci. Int. 2020, 311, 110275. [CrossRef] [PubMed]

97. Grassberger, M.; Frank, C. Temperature-related development of the parasitoid wasp Nasonia vitripennis as forensic indicator. Med. Vet. Entomol. 2003, 17, 257-262. [CrossRef] [PubMed]

98. Rivers, D.B.; Losinger, M. Development of the gregarious ectoparasitoid N asonia vitripennis using five species of necrophagous flies as hosts and at various developmental temperatures. Entomol. Exp. Appl. 2014, 151, 160-169. [CrossRef]

99. Voss, S.C.; Spafford, H.; Dadour, I.R. Temperature-dependant development of Nasonia vitripennis on five forensically important carrion fly species. Entomol. Exp. Appl. 2010, 135, 37-47. [CrossRef]

100. Zhang, Y.; Wang, Y.; Liu, C.; Wang, J.; Hu, G.; Wang, M.; Yang, L.; Chu, J. Development of Nasonia vitripennis (Hymenoptera: Pteromalidae) at constant temperatures in China. J. Med. Entomol. 2019, 56, 368-377. [CrossRef]

101. da Silva Mello, R.; Aguiar-Coelho, V.M. Durations of immature stage development period of Nasonia vitripennis (Walker)(Hymenoptera: Pteromalidae) under laboratory conditions: Implications for forensic entomology. Parasitol. Res. 2009, 104, 411-418. [CrossRef]

102. Matuszewski, S.; Hall, M.J.; Moreau, G.; Schoenly, K.G.; Tarone, A.M.; Villet, M.H. Pigs vs people: The use of pigs as analogues for humans in forensic entomology and taphonomy research. Int. J. Leg. Med. 2020, 134, 793-810. [CrossRef]

103. Matuszewski, S. Estimating the pre-appearance interval from temperature in Necrodes littoralis L. (Coleoptera: Silphidae). Forensic Sci. Int. 2011, 212, 180-188. [CrossRef] [PubMed]

104. Wells, J.D. A forensic entomological analysis can yield an estimate of postmortem interval, and not just a minimum postmortem interval: An explanation and illustration using a case. J. Forensic Sci. 2019, 64, 634-637. [CrossRef]

105. Matuszewski, S. A general approach for postmortem interval based on uniformly distributed and interconnected qualitative indicators. Int. J. Leg. Med. 2017, 131, 877-884. [CrossRef]

106. Matuszewski, S.; Mądra-Bielewicz, A. Validation of temperature methods for the estimation of pre-appearance interval in carrion insects. Forensic Sci. Med. Pathol. 2016, 12, 50-57. [CrossRef] [PubMed]

107. Matuszewski, S.; Szafałowicz, M.; Grzywacz, A. Temperature-dependent appearance of forensically useful flies on carcasses. Int. J. Leg. Med. 2014, 128, 1013-1020. [CrossRef] [PubMed]

108. Archer, M. Comparative Analysis of Insect Succession Data from Victoria (Australia) Using Summary Statistics versus Preceding Mean Ambient Temperature Models. J. Forensic Sci. 2014, 59, 404-412. [CrossRef] [PubMed]

109. VanLaerhoven, S. Blind validation of postmortem interval estimates using developmental rates of blow flies. Forensic Sci. Int. 2008, 180, 76-80. [CrossRef]

110. Peters, F.T.; Drummer, O.H.; Musshoff, F. Validation of new methods. Forensic Sci. Int. 2007, 165, 216-224. [CrossRef]

111. Goff, M.L. Early postmortem changes and stages of decomposition. In Current Concepts in Forensic Entomology; Amendt, J., Goff, M.L., Campobasso, C.P., Grassberger, M., Eds.; Springer: Dordrecht, Germany, 2010.

112. Schoenly, K.G.; Michaud, J.P.; Moreau, G. Design and analysis of field studies in carrion ecology. In Carrion Ecology, Evolution, and Their Applications; Benbow, M.E., Tomberlin, J.K., Tarone, A.M., Eds.; CRC Press: Boca Raton, FL, USA, 2016 ; pp. 129-148.

113. Schoenly, K.G.; Haskell, N.H.; Hall, R.D.; Gbur, J.R. Comparative performance and complementarity of four sampling methods and arthropod preference tests from human and porcine remains at the Forensic Anthropology Center in Knoxville, Tennessee. J. Med. Entomol. 2007, 44, 881-894. [CrossRef]

114. Schoenly, K.G.; Haskell, N.H.; Mills, D.K.; Bieme-Ndi, C.; Larsen, K.; Lee, Y. Recreating death's acre in the school yard: using pig carcasses as model corpses to teach concepts of forensic entomology \& ecological succession. Am. Biol. Teach. 2006, 68, 402-410. [CrossRef]

115. Schoenly, K.; Griest, K.; Rhine, S. An experimental field protocol for investigating the postmortem interval using multidisciplinary indicators. J. Forensic Sci. 1991, 36, 1395-1415. [CrossRef]

116. Tomberlin, J.; Byrd, J.; Wallace, J.; Benbow, M. Assessment of decomposition studies indicates need for standardized and repeatable research methods in forensic entomology. J. Forensic Res. 2012, 3, 147. [CrossRef]

117. Schoenly, K.; Goff, M.L.; Early, M. A BASIC algorithm for calculating the postmortem interval from arthropod successional data. J. Forensic Sci. 1992, 37, 808-823. [CrossRef]

118. Schoenly, K.; Goff, M.L.; Wells, J.D.; Lord, W.D. Quantifying statistical uncertainty in succession-based entomological estimates of the postmortem interval in death scene investigations: A simulation study. Am. Entomol. 1996, 42, 106-112. [CrossRef]

119. Matuszewski, S.; Bajerlein, D.; Konwerski, S.; Szpila, K. Insect succession and carrion decomposition in selected forests of Central Europe. Part 3: Succession of carrion fauna. Forensic Sci. Int. 2011, 207, 150-163. [CrossRef] 
120. Bonacci, T.; Brandmayr, P.; Greco, S.; Tersaruolo, C.; Vercillo, V.; Brandmayr, T.Z.B. A preliminary investigation of insect succession on carrion in Calabria (southern Italy). Terr. Arthropod Rev. 2010, 3, 97-110.

121. Prado e Castro, C.; Serrano, A.; Martins Da Silva, P.; García, M.D. Carrion flies of forensic interest: A study of seasonal community composition and succession in Lisbon, Portugal. Med. Vet. Entomol. 2012, 26, 417-431. [CrossRef]

122. Martín-Vega, D.; Nieto, C.M.; Cifrián, B.; Baz, A.; Díaz-Aranda, L.M. Early colonisation of urban indoor carcasses by blow flies (Diptera: Calliphoridae): An experimental study from central Spain. Forensic Sci. Int. 2017, 278, 87-94. [CrossRef]

123. Matuszewski, S.; Bajerlein, D.; Konwerski, S.; Szpila, K. An initial study of insect succession and carrion decomposition in various forest habitats of Central Europe. Forensic Sci. Int. 2008, 180, 61-69. [CrossRef] [PubMed]

124. Matuszewski, S.; Szafałowicz, M. Temperature-dependent appearance of forensically useful beetles on carcasses. Forensic Sci. Int 2013, 229, 92-99. [CrossRef] [PubMed]

125. Fratczak-Łagiewska, K.; Matuszewski, S. Resource partitioning between closely related carrion beetles: Thanatophilus sinuatus (F.) and Thanatophilus rugosus (L.)(Coleoptera: Silphidae). Entomol. Gen. 2018, 37, 143-156. [CrossRef]

126. Prado e Castro, C.; García, M.D.; Martins da Silva, P.; Faria e Silva, I.; Serrano, A. Coleoptera of forensic interest: A study of seasonal community composition and succession in Lisbon, Portugal. Forensic Sci. Int. 2013, 232, 73-83. [CrossRef] [PubMed]

127. Matuszewski, S. Estimating the Preappearance Interval from Temperature in Creophilus maxillosus L. (Coleoptera: Staphylinidae). J. Forensic Sci. 2012, 57, 136-145. [CrossRef] [PubMed]

128. Michaud, J.P.; Moreau, G. Predicting the visitation of carcasses by carrion-related insects under different rates of degree-day accumulation. Forensic Sci. Int. 2009, 185, 78-83. [CrossRef] [PubMed]

129. Higley, L.G.; Haskell, N.H. Insect development and forensic entomology. In Forensic Entomology: Utility of Arthropods in Legal Investigations; Byrd, J.H., Castner, J.L., Eds.; CRC Press: Boca Raton, FL, USA, 2001; pp. 287-302.

130. Archer, M.S. The effect of time after body discovery on the accuracy of retrospective weather station ambient temperature corrections in forensic entomology. J. Forensic Sci. 2004, 49, 553-559. [CrossRef] [PubMed]

131. Hofer, I.M.; Hart, A.J.; Martín-Vega, D.; Hall, M.J. Optimising crime scene temperature collection for forensic entomology casework. Forensic Sci. Int. 2017, 270, 129-138. [CrossRef] [PubMed]

132. Johnson, A.P.; Wallman, J.F.; Archer, M.S. Experimental and casework validation of ambient temperature corrections in forensic entomology. J. Forensic Sci. 2012, 57, 215-221. [CrossRef] [PubMed]

133. Hofer, I.M.; Hart, A.J.; Martín-Vega, D.; Hall, M.J. Estimating crime scene temperatures from nearby meteorological station data. Forensic Sci. Int. 2020, 306, 110028. [CrossRef]

134. Lutz, L.; Amendt, J. Stay cool or get hot? An applied primer for using temperature in forensic entomological case work. Sci. Justice 2020, 60, 415-422. [CrossRef] [PubMed]

135. Charabidze, D.; Hedouin, V. Temperature: The weak point of forensic entomology. Int. J. Leg. Med. 2019, 133, 633-639. [CrossRef]

136. Dourel, L.; Pasquerault, T.; Gaudry, E.; Benoît, V. Using Estimated On-Site Ambient Temperature Has Uncertain Benefit When Estimating Postmortem Interval. Psyche 2010, 2010, 1-7. [CrossRef]

137. Dadour, I.; Almanjahie, I.; Fowkes, N.; Keady, G.; Vijayan, K. Temperature variations in a parked vehicle. Forensic Sci. Int. 2011, 207, 205-211. [CrossRef]

138. Moreau, G.; Lutz, L.; Amendt, J. Honey, can you take out the garbage can? modeling weather data for cadavers found within containers. Pure Appl. Geophys. 2019, 1-12, in press. [CrossRef]

139. Michalski, M.; Nadolski, J. Thermal conditions in selected urban and semi-natural habitats, important for the forensic entomology. Forensic Sci. Int. 2018, 287, 153-162. [CrossRef] [PubMed]

140. Calla, L.; Bohun, C.; LeBlanc, H. Advancing the Forensic Estimation of Time Since Death. Pure Appl. Geophys. 2021, 1-11, in press.

141. Podhorna, J.; Aubernon, C.; Borkovcova, M.; Boulay, J.; Hedouin, V.; Charabidze, D. To eat or get heat: Behavioral trade-offs between thermoregulation and feeding in gregarious necrophagous larvae. Insect Sci. 2018, 25, 883-893. [CrossRef]

142. Aubernon, C.; Hedouin, V.; Charabidze, D. The maggot, the ethologist and the forensic entomologist: Sociality and thermoregulation in necrophagous larvae. J. Adv. Res. 2018, 16, 67-73. [CrossRef]

143. Aubernon, C.; Boulay, J.; Hédouin, V.; Charabidzé, D. Thermoregulation in gregarious dipteran larvae: Evidence of species-specific temperature selection. Entomol. Exp. Appl. 2016, 160, 101-108. [CrossRef]

144. Charabidze, D.; Bourel, B.; Gosset, D. Larval-mass effect: Characterisation of heat emission by necrophageous blowflies (Diptera: Calliphoridae) larval aggregates. Forensic Sci. Int. 2011, 211, 61-66. [CrossRef]

145. Gruner, S.V.; Slone, D.H.; Capinera, J.L.; Turco, M.P. Volume of larvae is the most important single predictor of mass temperatures in the forensically important calliphorid, Chrysomya megacephala (Diptera: Calliphoridae). J. Med. Entomol. 2016, 54, 30-34. [CrossRef] [PubMed]

146. Slone, D.H.; Gruner, S.V. Thermoregulation in larval aggregations of carrion-feeding blow flies (Diptera: Calliphoridae). J. Med. Entomol. 2007, 44, 516-523. [CrossRef] [PubMed]

147. Girard, M. Etudes sur la Chaleur Libre Degagee par les Animaux Invertebres et Specialement les Insectes; Victor Masson: Paris, France, 1869.

148. Turner, B.; Howard, T. Metabolic heat generation in dipteran larval aggregations: A consideration for forensic entomology. Med. Vet. Entomol. 1992, 6, 179-181. [CrossRef]

149. Rivers, D.B.; Thompson, C.; Brogan, R. Physiological trade-offs of forming maggot masses by necrophagous flies on vertebrate carrion. Bull. Entomol. Res. 2011, 101, 599-611. [CrossRef] 
150. Heaton, V.; Moffatt, C.; Simmons, T. Quantifying the temperature of maggot masses and its relationship to decomposition. J. Forensic Sci. 2014, 59, 676-682. [CrossRef]

151. Johnson, A.P.; Wallman, J.F. Effect of massing on larval growth rate. Forensic Sci. Int. 2014, 241, 141-149. [CrossRef] [PubMed]

152. Kotzé, Z.; Villet, M.H.; Weldon, C.W. Heat accumulation and development rate of massed maggots of the sheep blowfly, Lucilia cuprina (Diptera: Calliphoridae). J. Insect Physiol. 2016, 95, 98-104. [CrossRef] [PubMed]

153. Matuszewski, S.; Mądra-Bielewicz, A. Heat production in a feeding matrix formed on carrion by communally breeding beetles. Front. Zool. 2021, 18, 5. [CrossRef]

154. Johnson, A.P.; Wighton, S.J.; Wallman, J.F. Tracking movement and temperature selection of larvae of two forensically important blow fly species within a "maggot mass". J. Forensic Sci. 2014, 59, 1586-1591. [CrossRef]

155. Heaton, V.; Moffatt, C.; Simmons, T. The movement of fly (Diptera) larvae within a feeding aggregation. Can. Entomol. 2018, 150, 326-333. [CrossRef]

156. Gruszka, J.; Krystkowiak-Kowalska, M.; Frątczak-Łagiewska, K.; Mądra-Bielewicz, A.; Charabidze, D.; Matuszewski, S. Patterns and mechanisms for larval aggregation in carrion beetle Necrodes littoralis (Coleoptera: Silphidae). Anim. Behav. 2020, 162, 1-10. [CrossRef]

157. Szpila, K. Key for identification of European and Mediterranean blowflies (Diptera, Calliphoridae) of medical and veterinary importance-adult flies. In Forensic Entomology, an Introduction; Gennard, D., Ed.; Willey-Blackwell: Chichester, UK, $2012 ;$ pp. 77-81.

158. Akbarzadeh, K.; Wallman, J.F.; Sulakova, H.; Szpila, K. Species identification of Middle Eastern blowflies (Diptera: Calliphoridae) of forensic importance. Parasitol. Res. 2015, 114, 1463-1472. [CrossRef] [PubMed]

159. Lutz, L.; Williams, K.A.; Villet, M.H.; Ekanem, M.; Szpila, K. Species identification of adult African blowflies (Diptera: Calliphoridae) of forensic importance. Int. J. Leg. Med. 2018, 132, 831-842. [CrossRef]

160. Prado e Castro, C.; Szpila, K.; Martínez-Sánchez, A.I.; Rego, C.; Silva, I.; Serrano, A.R.M.; Boieiro, M. The blowflies of the Madeira Archipelago: Species diversity, distribution and identification (Diptera, Calliphoridae sl). ZooKeys 2016, 634, 101-123. [CrossRef] [PubMed]

161. Wallman, J. A key to the adults of species of blowflies in southern Australia known or suspected to breed in carrion. Med. Vet. Entomol. 2001, 15, 433-437. [CrossRef]

162. Szpila, K. Key for the identification of third instars of European blowflies (Diptera: Calliphoridae) of forensic importance. In Current Concepts in Forensic Entomology; Amendt, J., Campobasso, C.P., Goff, M.L., Grassberger, M., Eds.; Springer: Dordrecht, Germany, 2010; pp. 43-56.

163. Szpila, K.; Richet, R.; Pape, T. Third instar larvae of flesh flies (Diptera: Sarcophagidae) of forensic importance-Critical review of characters and key for European species. Parasitol. Res. 2015, 114, 2279-2289. [CrossRef]

164. Grzywacz, A.; Hall, M.J.; Pape, T.; Szpila, K. Muscidae (Diptera) of forensic importance-An identification key to third instar larvae of the western Palaearctic region and a catalogue of the muscid carrion community. Int. J. Leg. Med. 2017, 131, 855-866. [CrossRef] [PubMed]

165. Giordani, G.; Grzywacz, A.; Vanin, S. Characterization and identification of puparia of Hydrotaea Robineau-Desvoidy, 1830 (Diptera: Muscidae) from forensic and archaeological contexts. J. Med. Entomol. 2019, 56, 45-54. [CrossRef] [PubMed]

166. Díaz-Aranda, L.M.; Martín-Vega, D.; Baz, A.; Cifrián, B. Larval identification key to necrophagous Coleoptera of medico-legal importance in the western Palaearctic. Int. J. Leg. Med. 2018, 132, 1795-1804. [CrossRef]

167. Park, S.-H.; Moon, T.-Y. Carrion Beetles (Coleoptera, Silphidae) of Potential Forensic Importance and Their Pictorial Identification Key by User-Friendly Characters in Korea. Korean J. Leg. Med. 2020, 44, 143-149. [CrossRef]

168. Novák, M.; Jakubec, P.; Qubaiová, J.; Šuláková, H.; Růžička, J. Revisited larval morphology of Thanatophilus rugosus (Coleoptera: Silphidae). Int. J. Leg. Med. 2018, 132, 939-954. [CrossRef] [PubMed]

169. Jakubec, P.; Novák, M.; Qubaiová, J.; Šuláková, H.; Růžička, J. Description of immature stages of Thanatophilus sinuatus (Coleoptera: Silphidae). Int. J. Leg. Med. 2019, 133, 1549-1565. [CrossRef] [PubMed]

170. Ma, T.; Huang, J.; Wang, J.F. Study on the pupal morphogenesis of Chrysomya rufifacies (Macquart) (Diptera: Calliphoridae) for postmortem interval estimation. Forensic Sci. Int. 2015, 253, 88-93. [CrossRef]

171. Flissak, J.; Moura, M. Intrapuparial development of Sarconesia chlorogaster (Diptera: Calliphoridae) for postmortem interval estimation (PMI). J. Med. Entomol. 2018, 55, 277-284. [CrossRef] [PubMed]

172. da Silva, S.M.; Moura, M.O. Intrapuparial development of Hemilucilia semidiaphana (Diptera: Calliphoridae) and its use in forensic entomology. J. Med. Entomol. 2019, 56, 1623-1635. [CrossRef] [PubMed]

173. Ramos-Pastrana, Y.; Londoño, C.A.; Wolff, M. Intra-puparial development of Lucilia eximia (Diptera, Calliphoridae). Acta Amazon. 2017, 47, 63-70. [CrossRef]

174. Wang, Y.; Gu, Z.-y.; Xia, S.-x.; Wang, J.-f.; Zhang, Y.-n.; Tao, L.-y. Estimating the age of Lucilia illustris during the intrapuparial period using two approaches: Morphological changes and differential gene expression. Forensic Sci. Int. 2018, $287,1-11$. [CrossRef] [PubMed]

175. Salazar-Souza, M.; Couri, M.S.; Aguiar, V.M. Chronology of the intrapuparial development of the blowfly Chrysomya albiceps (Diptera: Calliphoridae): Application in forensic entomology. J. Med. Entomol. 2018, 55, 825-832. [CrossRef] [PubMed]

176. Wydra, J.; Matuszewski, S. The optimal post-eclosion interval while estimating the post-mortem interval based on an empty puparium. Forensic Sci. Med. Pathol. 2020, 1-7, in press. [CrossRef] [PubMed] 
177. Frere, B.; Suchaud, F.; Bernier, G.; Cottin, F.; Vincent, B.; Dourel, L.; Lelong, A.; Arpino, P. GC-MS analysis of cuticular lipids in recent and older scavenger insect puparia. An approach to estimate the postmortem interval (PMI). Anal. Bioanal. Chem. 2014, 406, 1081-1088. [CrossRef] [PubMed]

178. Moore, H.E.; Pechal, J.L.; Benbow, M.E.; Drijfhout, F.P. The potential use of cuticular hydrocarbons and multivariate analysis to age empty puparial cases of Calliphora vicina and Lucilia sericata. Sci. Rep. 2017, 7, 1-11. [CrossRef]

179. Zhu, G.-H.; Jia, Z.-J.; Yu, X.-J.; Wu, K.-S.; Chen, L.-S.; Lv, J.-Y.; Benbow, M.E. Predictable weathering of puparial hydrocarbons of necrophagous flies for determining the postmortem interval: A field experiment using Chrysomya rufifacies. Int. J. Leg. Med. 2017, 131, 885-894. [CrossRef]

180. Wells, J.D.; LaMotte, N.L. Estimating the postmortem interval. In Forensic Entomology: The Utility of Arthropods in Legal Investigations, 2nd ed.; Byrd, J.H., Castner, J.L., Eds.; CRC Press: Boca Raton, FL, USA, 2010; pp. 367-388.

181. Wells, J.; LaMotte, L.R. Estimating maggot age from weight using inverse prediction. J. Forensic Sci. 1995, 40, 585-590. [CrossRef]

182. Reibe, S.; Doetinchem, P.v.; Madea, B. A new simulation-based model for calculating post-mortem intervals using developmental data for Lucilia sericata (Dipt.: Calliphoridae). Parasitol. Res. 2010, 107, 9-16. [CrossRef]

183. Mohr, R.M.; Tomberlin, J.K. Development and validation of a new technique for estimating a minimum postmortem interval using adult blow fly (Diptera: Calliphoridae) carcass attendance. Int. J. Leg. Med. 2015, 129, 851-859. [CrossRef] [PubMed]

184. Villet, M.H.; Richards, C.S.; Midgley, J.M. Contemporary precision, bias and accuracy of minimum post-mortem intervals estimated using development of carrion-feeding insects. In Current Concepts in Forensic Entomology; Amendt, J., Campobasso, C.P., Goff, M.L., Grassberger, M., Eds.; Springer: Dordrecht, Germany, 2010; pp. 109-138.

185. Kashyap, V.; Pillay, V. Efficacy of entomological method in estimation of postmortem interval: A comparative analysis. Forensic Sci. Int. 1989, 40, 245-250. [CrossRef]

186. Goff, M.L.; Odom, C.B. Forensic entomology in the Hawaiian Islands. Three case studies. Am. J. Forensic Med. Pathol. 1987, 8, 45-50. [CrossRef]

187. Lutz, L.; Amendt, J. Precocious egg development in wild Calliphora vicina (Diptera: Calliphoridae)—An issue of relevance in forensic entomology? Forensic Sci. Int. 2020, 306, 110075. [CrossRef]

188. Richards, C.S.; Simonsen, T.J.; Abel, R.L.; Hall, M.J.; Schwyn, D.A.; Wicklein, M. Virtual forensic entomology: Improving estimates of minimum post-mortem interval with 3D micro-computed tomography. Forensic Sci. Int. 2012, 220, 251-264. [CrossRef]

189. Richards, C.; Rowlinson, C.; Cuttiford, L.; Grimsley, R.; Hall, M.R. Decomposed liver has a significantly adverse affect on the development rate of the blowfly Calliphora vicina. Int. J. Leg. Med. 2013, 127, 259-262. [CrossRef]

190. Richards, C.; Rowlinson, C.; Hall, M.R. Effects of storage temperature on the change in size of Calliphora vicina larvae during preservation in $80 \%$ ethanol. Int. J. Leg. Med. 2013, 127, 231-241. [CrossRef]

191. Myskowiak, J.-B.; Doums, C. Effects of refrigeration on the biometry and development of Protophormia terraenovae (RobineauDesvoidy)(Diptera: Calliphoridae) and its consequences in estimating post-mortem interval in forensic investigations. Forensic Sci. Int. 2002, 125, 254-261. [CrossRef]

192. Holmes, L.; Vanlaerhoven, S.; Tomberlin, J. Relative humidity effects on the life history of Hermetia illucens (Diptera: Stratiomyidae). Environ. Entomol. 2012, 41, 971-978. [CrossRef]

193. Bauer, A.; Bauer, A.M.; Tomberlin, J.K. Impact of diet moisture on the development of the forensically important blow fly Cochliomyia macellaria (Fabricius)(Diptera: Calliphoridae). Forensic Sci. Int. 2020, 312, 110333. [CrossRef] [PubMed]

194. Moffatt, C.; Heaton, V.; De Haan, D. The distribution of blow fly (Diptera: Calliphoridae) larval lengths and its implications for estimating post mortem intervals. Int. J. Leg. Med. 2016, 130, 287-297. [CrossRef]

195. Wells, J.D.; Lecheta, M.C.; Moura, M.O.; LaMotte, L.R. An evaluation of sampling methods used to produce insect growth models for postmortem interval estimation. Int. J. Leg. Med. 2015, 129, 405-410. [CrossRef]

196. Bernhardt, V.; Schomerus, C.; Verhoff, M.; Amendt, J. Of pigs and men-Comparing the development of Calliphora vicina (Diptera: Calliphoridae) on human and porcine tissue. Int. J. Leg. Med. 2017, 131, 847-853. [CrossRef]

197. Avila, F.W.; Goff, M.L. Arthropod succession patterns onto burnt carrion in two contrasting habitats in the Hawaiian Islands. J. Forensic Sci. 1998, 43, 581-586. [CrossRef] [PubMed]

198. Hewadikaram, K.A.; Goff, M.L. Effect of carcass size on rate of decomposition and arthropod succession patterns. Am. J. Forensic Med. Pathol. 1991, 12, 235-240. [CrossRef] [PubMed]

199. Shean, B.S.; Messinger, L.; Papworth, M. Observations of differential decomposition on sun exposed v. shaded pig carrion in coastal Washington State. J. Forensic Sci. 1993, 38, 938-949. [CrossRef] [PubMed]

200. Komar, D.; Beattie, O. Effects of Carcass Size on Decay Rates of Shade and Sun Exposed Carrion. Can. Soc. Forensic Sci. J. 1998, 31, 35-43. [CrossRef]

201. Shalaby, O.A.; deCarvalho, L.M.; Goff, M.L. Comparison of patterns of decomposition in a hanging carcass and a carcass in contact with soil in a xerophytic habitat on the Island of Oahu, Hawaii. J. Forensic Sci. 2000, 45, 1267-1273. [CrossRef]

202. VanLaerhoven, S.L.; Anderson, G.S. Insect succession on buried carrion in two biogeoclimatic zones of British Columbia. J. Forensic Sci. 1999, 44, 32-43. [CrossRef]

203. Schoenly, K.G.; Shahid, S.A.; Haskell, N.H.; Hall, R.D. Does carcass enrichment alter community structure of predaceous and parasitic arthropods? A second test of the arthropod saturation hypothesis at the Anthropology Research Facility in Knoxville, Tennessee. J. Forensic Sci. 2005, 50, 134-142. [CrossRef] 
204. Shahid, S.A.; Schoenly, K.; Haskell, N.H.; Hall, R.D.; Zhang, W. Carcass enrichment does not alter decay rates or arthropod community structure: A test of the arthropod saturation hypothesis at the anthropology research facility in Knoxville, Tennessee. J. Med. Entomol. 2003, 40, 559-569. [CrossRef] [PubMed]

205. Archer, M.S. Annual variation in arrival and departure times of carrion insects at carcasses: Implications for succession studies in forensic entomology. Aust. J. Zool. 2004, 51, 569-576. [CrossRef]

206. Archer, M.S.; Elgar, M.A. Effects of decomposition on carcass attendance in a guild of carrion-breeding flies. Med. Vet. Entomol. 2003, 17, 263-271. [CrossRef]

207. Wang, J.; Li, Z.; Chen, Y.; Chen, Q.; Yin, X. The succession and development of insects on pig carcasses and their significances in estimating PMI in south China. Forensic Sci. Int. 2008, 179, 11-18. [CrossRef] [PubMed]

208. Sharanowski, B.J.; Walker, E.G.; Anderson, G.S. Insect succession and decomposition patterns on shaded and sunlit carrion in Saskatchewan in three different seasons. Forensic Sci. Int. 2008, 179, 219-240. [CrossRef]

209. McIntosh, C.S.; Dadour, I.R.; Voss, S.C. A comparison of carcass decomposition and associated insect succession onto burnt and unburnt pig carcasses. Int. J. Leg. Med. 2016. [CrossRef]

210. Voss, S.C.; Cook, D.F.; Dadour, I.R. Decomposition and insect succession of clothed and unclothed carcasses in Western Australia. Forensic Sci. Int. 2011, 211, 67-75. [CrossRef] [PubMed]

211. Voss, S.C.; Spafford, H.; Dadour, I.R. Annual and seasonal patterns of insect succession on decomposing remains at two locations in Western Australia. Forensic Sci. Int. 2009, 193, 26-36. [CrossRef] [PubMed]

212. Voss, S.C.; Forbes, S.L.; Dadour, I.R. Decomposition and insect succession on cadavers inside a vehicle environment. Forensic Sci. Med. Pathol. 2008, 4, 22-32. [CrossRef]

213. Michaud, J.P.; Moreau, G. Effect of variable rates of daily sampling of fly larvae on decomposition and carrion insect community assembly: Implications for forensic entomology field study protocols. J. Med. Entomol. 2013, 50, 890-897. [CrossRef] [PubMed]

214. Michaud, J.P.; Moreau, G. A statistical approach based on accumulated degree-days to predict decomposition-related processes in forensic studies. J. Forensic Sci. 2011, 56, 229-232. [CrossRef] [PubMed]

215. Michaud, J.P.; Majka, C.G.; Prive, J.P.; Moreau, G. Natural and anthropogenic changes in the insect fauna associated with carcasses in the North American Maritime lowlands. Forensic Sci. Int. 2010, 202, 64-70. [CrossRef] [PubMed]

216. Matuszewski, S.; Bajerlein, D.; Konwerski, S.; Szpila, K. Insect succession and carrion decomposition in selected forests of Central Europe. Part 1: Pattern and rate of decomposition. Forensic Sci. Int. 2010, 194, 85-93. [CrossRef] [PubMed]

217. Reibe, S.; Madea, B. How promptly do blowflies colonise fresh carcasses? A study comparing indoor with outdoor locations. Forensic Sci. Int. 2010, 195, 52-57. [CrossRef]

218. Bugajski, K.N.; Seddon, C.C.; Williams, R.E. A comparison of blow fly (Diptera: Calliphoridae) and beetle (Coleoptera) activity on refrigerated only versus frozen-thawed pig carcasses in Indiana. J. Med. Entomol. 2011, 48, 1231-1235. [CrossRef]

219. Ahmad, A.; Ahmad, A.H.; Dieng, H.; Satho, T.; Ahmad, H.; Aziz, A.T.; Boots, M. Cadaver wrapping and arrival performance of adult flies in an oil palm plantation in northern peninsular Malaysia. J. Med. Entomol. 2011, 48, 1236-1246. [CrossRef]

220. Anderson, G.S. Comparison of decomposition rates and faunal colonization of carrion in indoor and outdoor environments. J. Forensic Sci. 2011, 56, 136-142. [CrossRef]

221. Kelly, J.A.; van der Linde, T.C.; Anderson, G.S. The influence of wounds, severe trauma, and clothing, on carcass decomposition and arthropod succession in South Africa. Can. Soc. Forensic Sci. J. 2011, 44, 144-157. [CrossRef]

222. Kelly, J.A.; van der Linde, T.C.; Anderson, G.S. The influence of clothing and wrapping on carcass decomposition and arthropod succession during the warmer seasons in central South Africa. J. Forensic Sci. 2009, 54, 1105-1112. [CrossRef]

223. Gunn, A.; Bird, J. The ability of the blowflies Calliphora vomitoria (Linnaeus), Calliphora vicina (Rob-Desvoidy) and Lucilia sericata (Meigen) (Diptera: Calliphoridae) and the muscid flies Muscina stabulans (Fallen) and Muscina prolapsa (Harris) (Diptera: Muscidae) to colonise buried remains. Forensic Sci. Int. 2011, 207, 198-204. [CrossRef]

224. Sutherland, A.; Myburgh, J.; Steyn, M.; Becker, P.J. The effect of body size on the rate of decomposition in a temperate region of South Africa. Forensic Sci. Int. 2013, 231, 257-262. [CrossRef] [PubMed]

225. Perez, A.E.; Haskell, N.H.; Wells, J.D. Commonly Used Intercarcass Distances Appear to Be Sufficient to Ensure Independence of Carrion Insect Succession Pattern. Ann. Entomol. Soc. Am. 2016, 109, 72-80. [CrossRef]

226. Perez, A.E.; Haskell, N.H.; Wells, J.D. Evaluating the utility of hexapod species for calculating a confidence interval about a succession based postmortem interval estimate. Forensic Sci. Int. 2014, 241, 91-95. [CrossRef] [PubMed]

227. Matuszewski, S.; Konwerski, S.; Fratczak, K.; Szafalowicz, M. Effect of body mass and clothing on decomposition of pig carcasses. Int. J. Leg. Med. 2014, 128, 1039-1048. [CrossRef] [PubMed]

228. Cammack, J.A.; Cohen, A.C.; Kreitlow, K.L.; Roe, R.M.; Watson, D.W. Decomposition of Concealed and Exposed Porcine Remains in the North Carolina Piedmont. J. Med. Entomol. 2016, 53, 67-75. [CrossRef]

229. Charabidze, D.; Hedouin, V.; Gosset, D. An experimental investigation into the colonization of concealed cadavers by necrophagous blowflies. J. Insect Sci. 2015, 15, 149. [CrossRef]

230. Matuszewski, S.; Mądra, A. Factors affecting quality of temperature models for the pre-appearance interval of forensically useful insects. Forensic Sci. Int. 2015, 247, 28-35. [CrossRef]

231. Wang, Y.; Wang, J.; Wang, Z.; Tao, L. Insect succession on pig carcasses using different exposure time-A preliminary study in Guangzhou, China. J. Forensic Leg. Med. 2017, 52, 24-29. [CrossRef] 
232. Wang, Y.; Ma, M.Y.; Jiang, X.Y.; Wang, J.F.; Li, L.L.; Yin, X.J.; Wang, M.; Lai, Y.; Tao, L.Y. Insect succession on remains of human and animals in Shenzhen, China. Forensic Sci. Int. 2017, 271, 75-86. [CrossRef]

233. Mądra-Bielewicz, A.; Frątczak-Łagiewska, K.; Matuszewski, S. Sex-and Size-Related Patterns of Carrion Visitation in Necrodes littoralis (Coleoptera: Silphidae) and Creophilus maxillosus (Coleoptera: Staphylinidae). J. Forensic Sci. 2017, 62, 1229-1233. [CrossRef]

234. Cruise, A.; Hatano, E.; Watson, D.W.; Schal, C. Comparison of techniques for sampling adult necrophilous insects from pig carcasses. J. Med. Entomol. 2018, 55, 947-954. [CrossRef] [PubMed]

235. Knobel, Z.; Ueland, M.; Nizio, K.D.; Patel, D.; Forbes, S.L. A comparison of human and pig decomposition rates and odour profiles in an Australian environment. Aust. J. Forensic Sci. 2019, 51, 557-572. [CrossRef]

236. Steadman, D.W.; Dautartas, A.; Kenyhercz, M.W.; Jantz, L.M.; Mundorff, A.; Vidoli, G.M. Differential Scavenging among Pig, Rabbit, and Human Subjects. J. Forensic Sci. 2018. [CrossRef]

237. Dautartas, A.; Kenyhercz, M.W.; Vidoli, G.M.; Meadows Jantz, L.; Mundorff, A.; Steadman, D.W. Differential Decomposition Among Pig, Rabbit, and Human Remains. J. Forensic Sci. 2018. [CrossRef]

238. Connor, M.; Baigent, C.; Hansen, E.S. Testing the Use of Pigs as Human Proxies in Decomposition Studies. J. Forensic Sci. 2017. [CrossRef]

239. Dawson, B.M.; Barton, P.S.; Wallman, J.F. Contrasting insect activity and decomposition of pigs and humans in an Australian environment: A preliminary study. Forensic Sci. Int. 2020, 316, 110515. [CrossRef] [PubMed]

240. Jarmusz, M.; Bajerlein, D. Decomposition of hanging pig carcasses in a forest habitat of Poland. Forensic Sci. Int. 2019, 300, 32-42. [CrossRef]

241. Bourel, B.; Callet, B.; Hedouin, V.; Gosset, D. Flies eggs: A new method for the estimation of short-term post-mortem interval? Forensic Sci. Int. 2003, 135, 27-34. [CrossRef]

242. Faris, A.; West, W.; Tomberlin, J.; Tarone, A. Field validation of a development data set for Cochliomyia macellaria (Diptera: Calliphoridae): Estimating insect age based on development stage. J. Med. Entomol. 2020, 57, 39-49. [CrossRef]

243. Faris, A.; Wang, H.-H.; Tarone, A.; Grant, W. Forensic entomology: Evaluating uncertainty associated with postmortem interval (PMI) estimates with ecological models. J. Med. Entomol. 2016, 53, 1117-1130. [CrossRef] [PubMed]

244. Harnden, L.M.; Tomberlin, J.K. Effects of temperature and diet on black soldier fly, Hermetia illucens (L.)(Diptera: Stratiomyidae), development. Forensic Sci. Int. 2016, 266, 109-116. [CrossRef] [PubMed]

245. Voss, S.C.; Magni, P.; Dadour, I.; Nansen, C. Reflectance-based determination of age and species of blowfly puparia. Int. J. Leg. Med. 2017, 131, 263-274. [CrossRef] [PubMed]

246. Tarone, A.M.; Foran, D.R. Generalized additive models and Lucilia sericata growth: Assessing confidence intervals and error rates in forensic entomology. J. Forensic Sci. 2008, 53, 942-948. [CrossRef] [PubMed]

247. Reibe-Pal, S.; Madea, B. Calculating time since death in a mock crime case comparing a new computational method (ExLAC) with the ADH method. Forensic Sci. Int. 2015, 248, 78-81. [CrossRef]

248. Weatherbee, C.R.; Pechal, J.L.; Stamper, T.; Benbow, M.E. Post-Colonization Interval Estimates Using Multi-Species Calliphoridae Larval Masses and Spatially Distinct Temperature Data Sets: A Case Study. Insects 2017, 8, 40. [CrossRef]

249. Pittner, S.; Bugelli, V.; Weitgasser, K.; Zissler, A.; Sanit, S.; Lutz, L.; Monticelli, F.; Campobasso, C.P.; Steinbacher, P.; Amendt, J. A field study to evaluate PMI estimation methods for advanced decomposition stages. Int. J. Leg. Med. 2020, 134, 1361-1373. [CrossRef]

250. Turner, B.; Wiltshire, P. Experimental validation of forensic evidence: A study of the decomposition of buried pigs in a heavy clay soil. Forensic Sci. Int. 1999, 101, 113-122. [CrossRef]

251. Bhadra, P.; Hart, A.; Hall, M. Factors affecting accessibility to blowflies of bodies disposed in suitcases. Forensic Sci. Int. 2014, 239, 62-72. [CrossRef]

252. Goff, M.L.; Omori, A.I.; Gunatilake, K. Estimation of postmortem interval by arthropod succession. Three case studies from the Hawaiian Islands. Am. J. Forensic Med. Pathol. 1988, 9, 220-225. [CrossRef]

253. Pohjoismäki, J.L.; Karhunen, P.J.; Goebeler, S.; Saukko, P.; Sääksjärvi, I.E. Indoors forensic entomology: Colonization of human remains in closed environments by specific species of sarcosaprophagous flies. Forensic Sci. Int. 2010, 199, 38-42. [CrossRef]

254. Bugelli, V.; Forni, D.; Bassi, L.A.; Di Paolo, M.; Marra, D.; Lenzi, S.; Toni, C.; Giusiani, M.; Domenici, R.; Gherardi, M. Forensic entomology and the estimation of the minimum time since death in indoor cases. J. Forensic Sci. 2015, 60, 525-531. [CrossRef] [PubMed]

255. Goff, M.L.; Flynn, M.M. Determination of postmortem interval by arthropod succession: A case study from the Hawaiian Islands. J. Forensic Sci. 1991, 36, 607-614. [CrossRef] [PubMed]

256. Goff, M.; Odom, C.; Early, M. Estimation of post-mortem interval by entomological techniques: A case study from Oahu, Hawaii. Bull. Soc. Vector Ecol. 1986, 11, 242-246. 